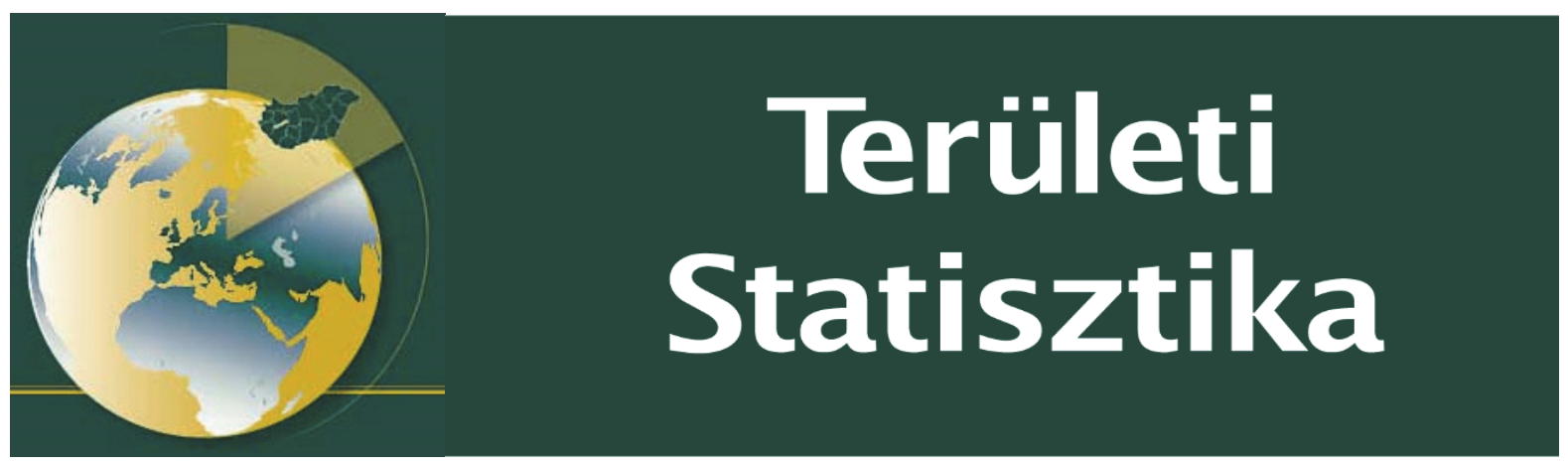

Közzététel: 2020. szeptember 21.

A tanulmány címe:

A munkanélküliség és a közfoglalkoztatás területi különbségei, összefüggései Magyarországon

Szerző:

Kóti Tibor

https://doi.org/10.15196/TS600501

Az alábbi feltételek érvényesek minden, a Központi Statisztikai Hivatal (a továbbiakban: KSH) Területi Statisztika c. folyóiratában (a továbbiakban: Folyóirat) megjelenö tanulmányra. Felhasználó a tanulmány, vagy annak részei felhasználásával egyidejüleg tudomásul veszi a jelen dokumentumban foglalt felhasználási feltételeket, és azokat magára nézve kötelezónek fogadja el. Tudomásul veszi, hogy a jelen feltételek megszegéséböl eredó valamennyi kárért felelösséggel tartozik.

1) A jogszabályi tartalom kivételével a tanulmányok a szerzői jogról szóló 1999. évi LXXVI. törvény (Szjt.) szerint szerzői műnek minősülnek. A szerzői jog jogosultja a KSH.

2) A KSH földrajzi és időbeli korlátozás nélküli, nem kizárólagos, nem átadható, térítésmentes felhasználási jogot biztosít a Felhasználó részére a tanulmány vonatkozásában.

3) A felhasználási jog keretében a Felhasználó jogosult a tanulmány:

a) oktatási és kutatási célú felhasználására (nyilvánosságra hozatalára és továbbítására a

4. pontban foglalt kivétellel) a Folyóirat és a szerző(k) feltüntetésével;

b) tartalmáról összefoglaló készítésére az írott és az elektronikus médiában a Folyóirat

és a szerző(k) feltüntetésével;

c) részletének idézésére - az átvevő mű jellege és célja által indokolt terjedelemben és az eredetihez híven - a forrás, valamint az ott megjelölt szerző(k) megnevezésével.

4) A Felhasználó nem jogosult a tanulmány továbbértékesítésére, haszonszerzési célú felhasználására. Ez a korlátozás nem érinti a tanulmány felhasználásával előállított, de az Szjt. szerint önálló szerzői műnek minősülő mű ilyen célú felhasználását.

5) A tanulmány átdolgozása, újra publikálása tilos.

6) A 3. a)-c.) pontban foglaltak alapján a Folyóiratot és a szerző(ke)t az alábbiak szerint kell feltüntetni:

„Forrás: Területi Statisztika c. folyóirat 60. évfolyam 5. sqámában megjelent, Kóti Tibor által irt, A munkanélkë̈liség és a kö̈foglalk.oztatás területi különbségei, összefüggései Magyarországon c. tanulmány”

7) A Folyóiratban megjelenő tanulmányok kutatói véleményeket tükröznek, amelyek nem esnek szükségképpen egybe a KSH, vagy a szerzők által képviselt intézmények hivatalos álláspontjával. 


\section{A munkanélküliség és a közfoglalkoztatás területi különbségei, összefüggései Magyarországon}

\section{Territorial differences and correlations of unemployment and workfare employment in Hungary}

\author{
Kóti, Tibor \\ Debreceni Egyetem \\ E-mail: tiborkoti7@gmail.com
}

Jelen tanulmány az elsődleges és a másodlagos munkaerôpiaci sérülékenységet leginkább meghatározó munkanélküliségi és közfoglalkoztatási folyamatok hazai területi különbségeit, összefüggéseit elemzi, a területi különbségekből fakadó esélyhátrányokra fókuszálva. Míg a munkanélküliségi folyamatokat az ezredfordulótól kezdődően, addig a közfoglalkoztatás hatását - a rendelkezésre álló adatok tükrében - a 2014 és 2018 közötti időszakban mutatja be, kiemelve az időbeli változásokból fakadó differenciálódást. A szerző külön figyelmet szentel a munkanélküliség alakulását jelentősen befolyásoló településszerkezeti sajátosságoknak is. A településnagyságtól és a centrumtérségektôl való távolsággal jól megragadható a munkaerópiaci sérülékenység. Megállapítható, hogy minél kisebb, illetve minél messzebb helyezkedik el egy település a központtól, annál magasabb munkanélküliség kumulálódik. Jelen vizsgálat relevanciáját igazolja, hogy az egyre növekvő munkaerőkereslet felveti a munkaadói igények kielégítésének kérdését. Mindehhez a közfoglalkoztatás foglalkoztató hatásának területi feltérképezése, mint potenciális munkaerőt kibocsát(hat)ó eszköz elsődleges munkaerőpiaci integrációja, tranzitív szerepköre releváns

Kulcsszavak: munkanélküliség, munkaerőpiac, közfoglalkoztatás, iskolázottság, területi differenciáltság kérdés, amit szintén vizsgál a szerző. A tanulmány elemzi továbbá a munkanélküliek és a közfoglalkoztatottak iskolázottsági összefüggéseinek alakulását, amellyel leginkább magyarázható a versenyszféra munkaerőpiacától való távolmaradás alakulása. 
The present study analyses the territorial differences and correlations of unemployment and workfare employment processes that determine the primary and secondary labour market vulnerabilities the most, focusing on disadvantages arising from territorial differences. Using available data, it presents unemployment trends since the turn of the millennium and the impact of workfare employment in the period between 2014 and 2018, highlighting the differentiation resulting from changes over time. Settlement structure patterns that significantly affect unemployment receive special attention from the author. Labour market vulnerability can be well presented with size of settlement and its distance from the central areas. It can be stated that the smaller a settlement or farther from the centre, the higher the unemployment rate. A growing demand for labour raises the question of meeting employer needs, justifying the relevance of the present study. Workfare employment is a potentially labour-emitting tool, a tool that helps the primary labour market integration in a transitive way, therefore the author examines the employment impact of

Keywords: unemployment, labour market, workfare employment, education, territorial differentiation workfare employment from a territorial point of view. The study also analyses the relationship between unemployment and educational attainment in relation to exclusion from the labour market and participation in public work programs.

Beküldve: 2020. március 29.

Elfogadva: 2020. május 12.

\section{Bevezetés}

A munkaerôpiaci folyamatokat leginkább meghatározó foglalkoztatottság és munkanélküliség kettőssége a regionális tudomány gyakorta változó, s egyben „örökzöld” kutatási témája. Az egyre inkább beskatulyázódó magyarországi munkaerőpiaci területi differenciáltság kérdésköre, azaz a centrum- és perifériaviszonyok elmúlt 3 évtizedbeli „megmerevedése” a területfejlesztési politika egyik sarkalatos pontja.

Területi Statisztika, 2020, 60(5): 517-547; DOI: 10.15196/TS600501 
Az elmúlt évek gazdasági fejlődésével összefüggésben - területileg ugyan nagy különbségekkel - de egyes térségekben (főként a centrális funkciókat ellátó térségekben) jelentős munkaerőhiány alakult ki, szemben a magas munkanélküliséggel sújtott térségtípusokkal (KSH 2019, Tagai et al. 2018). Éppen ezért, a periferikus térségekben élő, hátrányos helyzetủ, gazdaságilag aktív korúak (Rozgonyi-Horváth 2018) - jelen kutatásban fóként a munkanélküliek és a közfoglalkoztatásban részt vevők - aktivizálása minden eddiginél fontosabb feladat Magyarországon, amely elsősorban a munkaerőpiaci kereslet és kínálat diszharmonikus területi egyenlőtlenségeinek mérséklődésében játszhat kulcsszerepet.

A közfoglalkoztatás sikerességéről megoszlanak a kutatói vélemények. A 2008. évi világgazdasági válsággal kialakult recesszió következtében a közvetlen munkahelyteremtésbe, majd a válság enyhülése után a képzésekbe való beruházás az aktív munkaerőpiaci politika kiemelt eleme. A hazai nagyvárosok - utóbbi években mutatott - gazdasági expanziója (a foglalkoztatottsági ráta növekedése) (Molnár et al. 2018, Rechnitzer 2019) mellett a támogatott közfoglalkoztatási programok egyaránt fontos tényezői a vizsgált időszakban egyre csökkenő munkanélküliségnek.

További kérdés az is, hogy a gazdaságfejlesztési interakciók következtében az egyes térségekben kialakuló és a jövőben egyre növekvő munkaerő-szükséglethez az emberi tôke megfelelő mennyiségben és minőségben egyaránt biztosítható-e? Mindez fontos nemzetgazdasági kérdéseket feszeget, ugyanis a külföldi tőkéből megvalósuló beruházások hazai adaptálása, jövőbeli intenzitása szempontjából alapvető, hogy a potenciális befektetők igénye kielégithetô-e képzett, kvalifikált munkaerővel.

A közfoglalkoztatás tranzitív szerepköre, elsődleges munkaerőpiaci megfelelőssége területileg rendkívül differenciált. A periferikus térségek sajátosságaiból fakadó esélyhátrányok (alacsony munkaerő-kínálat, a mobilizációs feltételek ellehetetlenülése stb.) meghatározzák a közfoglalkoztatás hatékonyságát, az elsődleges munkaerőpiaci (re)integrációt, azaz a versenyszféra munkaerőigényének kielégítését (Kóti 2018, 2019, Alpek et al. 2018, Alpek-Tésits 2019a).

Jelen tanulmány legfontosabb célja a munkanélküliség és a hazai közfoglalkoztatás szinergikus, területi alapú, dinamikus vizsgálata, a legkarakteresebb munkanélküliséggel sújtott térségek és települések, továbbá a közfoglalkoztatás napjaink munkaerőpiaci folyamataiban betöltött szerepének és a foglalkoztatottságra gyakorolt hatásának kimutatása.

A területi elemzés előtt áttekintjük a hazai elsődleges és másodlagos munkaerőpiac ezredfordulót követő főbb változásait, egymáshoz való viszonyrendszerüket, a teljesség igénye nélkül, ugyanakkor bízva a két évtizedes múltra visszatekintő szakirodalmi másodelemzés hasznosságában. Az alkalmazott módszertan ismertetése után sorra vesszük az elsődleges munkaerőpiaci sérülékenységet leginkább megragadó munkanélküliség területi változásait, illetve a térszerkezeti sajátosságokból fakadó eltérő folyamatokat az ezredfordulótól, valamint feltárjuk a közfoglalkoztatásnak a hazai foglalkoztatáspolitikában betöltött szerepkörét, foglalkoztatásra gyakorolt

Területi Statisztika, 2020, 60(5): 517-547; DOI: 10.15196/TS600501 
hatását. Ezt követően a munkanélküliség és a közfoglalkoztatás iskolázottsági összefüggéseit vesszük górcső alá, azzal a céllal, hogy felhívjuk a figyelmet az emberierőforrás-fejlesztés szerepének fontosságára.

\section{Elsődleges és másodlagos munkaeröpiaci változások az ezredfordulótól}

A munkaerôpiaci folyamatok heterogenitása, változékonysága révén a tudományos írások az elmúlt években számos szempontból megközelítették a foglalkoztatottságot és a munkanélküliséget differenciáló tényezők körét, ennek ismeretében érdemes áttekinteni a legfontosabb paradigmákat, az ezredfordulótól egészen napjainkig tartó időszakban a legfontosabb elsődleges és az ahhoz illeszkedő másodlagos munkaerôpiaci változásokat.

Az ezredforduló tájékán, a rendszerváltás okozta jelentôs hazai munkaerőpiaci leépülés következtében kialakuló markáns, egyes térségeket halmozottan sújtó vulnerabilitás az 1990-es évek közepétől némileg ugyan, de oldódni látszott (munkanélküliségi arány 2000-ben: 8,7\%) (Laky 2002).

A 2000-es évek eleji munkaerőpiaci területi egyenlőtlenségi sémákat nagymértékben meghatározták a különböző gazdasági ágazatok lokalitásai. A rendszerváltás maradandó sokkjának tekinthető a primer szektor (kollektivizálás, termelőszövetkezetek leépítése stb.) leépülése, ami jelentős számú munkaerôt szabadított fel az elsődleges munkaerőpiacról. A tercier szektor térnyerése - különösen a magas munkanélküliséggel sújtott térségekben - kevésbé jellemző. Ebből adódóan a szekunder szektor, azaz az ipari térségek, az ipari fejlődési pályák nagyban meghatározták a foglalkoztatottság és munkanélküliség alakulását (Balcsók 2005).

Az ezredfordulót követô gazdasági expanziót, s ezáltal a munkához való jutást az európai uniós csatlakozást megalapozó pénzügyi támogatások kedvezőbb irányba formálták. Különösen az eredetileg Lengyelország és Magyarország részére, gazdasági reformjaik végrehajtására 1989-ben alapított pénzügyi segítő (Poland and Hungary: Assistance for Restructuring their Economies - PHARE) -program keretében, amely az egyik legfontosabb feladatának - az uniós források fogadására irányuló intézményi fejlesztés mellett - a kis- és középvállalkozások támogatását tekintette (Kozma 2010). Az Európai Unióhoz való csatlakozás után jelentősen nőttek a hazánkba áramló fejlesztési források. Mindez a külföldi múködő tőke hazaitelephelyválasztásával, a foglalkoztatottság növekedésével, illetve a munkanélküliség visszaszorításával kecsegtetett.

A 2008. évi világgazdasági válság azonban jelentősen átformálta hazánk munkaerőpiacát, amely ugyan különböző mértékủ, de makroszintű területi átrendeződéssel járt. A gazdasági recesszió nem csupán az elmaradott térségek munkaerőpiacát tette jelentôsen sérülékennyé (fokozódó munkanélküliségi szint) (Alpek-Tésits 2014), hanem a fejlettebb gazdasági potenciálú térségekét is (Egedy 2012). A válság ha-

Területi Statisztika, 2020, 60(5): 517-547; DOI: 10.15196/TS600501 
zánkra irányuló depresszív, s jelentősen leépülő munkaerôpiaci tüneteiben nagy szerepet játszott a válság kirobbanását megelőző csekély gazdasági teljesítőképesség, az erőltetett túlköltekezés, illetve az alacsony szintű versenyképesség (Békesi 2011).

A gazdasági leépülés mindenekelőtt az exportorientált ipari ágazatokat érintette legérzékenyebben. A legjelentősebb gazdasági recesszió az iparilag prosperáló térségekben következett be. Éppen ezért Közép-Dunántúl, Közép-Magyarország és Nyugat-Dunántúl esetében volt legnagyobb mértékủ a termelés visszaesése és a létszámleépítés. A belföldi piacok visszaesése némi késéssel következett be, azonban jóval hosszabb lefolyású volt, s egyre több ágazatot érintett. A gazdasági recesszió második szakaszának legjelentősebb vesztesei a válságot megelőzően is markáns területi hátrányokkal jellemezhető térségtípusok, a leghátrányosabb helyzetű kistérségek voltak. Észak-Alföld, Észak-Magyarország és Dél-Dunántúl vállalatainak tömeges csődjei tovább növelték a munkanélküliek amúgy is magas számát (Lőcsei 2010, Faluvégi 2010, Barta-Lőcsei 2011, Egedy 2012, Szabó 2013).

A 2008. évi világgazdasági válság következtében kialakuló magas munkanélküliség csökkentésében nagy szerepet játszottak a 2010 utáni új gazdaságpolitikai intézkedések. A legfontosabb tényezők között a munkaalapú gazdaság (welfare to workfare) elótérbe helyezése, az egységes közfoglalkoztatás bevezetése, a hazai kisés középvállalkozások megerősítése (a foglalkoztatás ösztönzése járulékcsökkentés révén), az exportorientált szektorok, valamint a tőkevonzó képesség erősítése és a nagyvállalati szektor növekvő megjelenése említhetőek (György-Veress 2016).

A magyar foglalkoztatáspolitika legfőbb és legszembetűnőbb beavatkozásai, reformjai mindig valamilyen válságot követő munkaerőpiaci sokk következtében kialakuló válságidőszakokban történtek (Kálmán 2015). Mindez az aktív munkaerőpiaci eszközök egyre dinamikusabb térnyerését is jelentette. Ezen eszközök alkalmazásának - a nemzetközi trendekhez hasonlóan (Card et al. 2010) - az a legfőbb célja, hogy javítsa az elhelyezkedési lehetôségeket, növelje az érintettek készségeit, kompetenciáit, fejlessze a munka ösztönzését, elősegítse a munkaerő újraelosztását a különböző piacok között és nem utolsósorban makroszinten növelje a gazdasági teljesítményt (Kovács-Ráczné 2011).

Az aktív munkaerőpiaci eszközöknek számos típusa különböztethető meg: képzések, közvetlen munkahelyteremtési eszközök, bértámogatások, vállalkozóknak nyújtott kedvezmények stb. (Bonoli 2010, Kluve 2010). Magyarországon legjelentősebb hagyományai a közvetlen munkahelyteremtési, azaz közfoglalkoztatási programoknak vannak, amelyek több ízben, egészen a rendszerváltástól napjainkig szervesen hozzájárultak a versenyszféra munkaerőpiacáról kiszorultak foglalkoztatásához. Az ezredfordulót megelőző közhasznú, közmunka, közcélú programok hasonló célt szolgáltak, mint a 2011-ben bevezetett egységes közfoglalkoztatás (2011. évi CVI. törvény): elősegíteni az elsődleges munkaerôpiacról kiszoruló, hátrányos helyzetúek munkához való jutását, valamint elsődleges munkaerőpiaci (re)integrációját (Csoba 2010).

Területi Statisztika, 2020, 60(5): 517-547; DOI: 10.15196/TS600501 
A válság okozta foglalkoztatási traumák enyhítésére, az „Út a munkához” program 2009. évi bevezetése, majd a 2011-ben megreformált hazai közmunkarendszer révén kialakított egységes közfoglalkoztatás jelentős számú munkavállalónak nyújtott átmeneti foglalkoztatást, jövedelemszerzési lehetőséget (Cseres-Gergely-Molnár 2015, Kóti 2018), főként a vidéki Magyarországon (Váradi 2016), ahol olykor az egyetlen jövedelemszerzési forrást ez a foglalkoztatáspolitikai eszköz jelenti (Rozgonyi-Horváth 2018).

Napjaink foglalkoztathatósági viszonyait leginkább a társadalmi-gazdasági környezet, a képzettség és a mobilitási feltételek határozzák meg (Alpek-Tésits 2019b). Ennek tükrében talán nem meglepő, hogy a legnagyobb különbségek a városok és a községek között figyelhetők meg. A foglalkoztathatóság továbbá jelentős szignifikanciát mutat az elérhetőség kérdéskörével (Tóth 2018, Alpek-Tésits 2019b), a ruralitás mértékével (Obádovics 2004), a nagyvállalati beágyazódással (Józsa 2017), illetve az ingázási relációk lokális alakulásával (Pénzes 2013, Kiss-Szalkai 2018).

\section{Alkalmazott módszertan}

Jelen kutatás a munkanélküliség alakulásának dinamikus vizsgálatát a hazai térfolyamatok különböző szintjein (régió, járás, település) végzi el, figyelembe véve az egyes területi szintek belső differenciálódásának folyamatait is.

A munkanélküliség ${ }^{1}$ alakulásának mérésére a munkanélküliségi rátát ${ }^{2}$ alkalmaztam. Egyes térségekben a sérülékenység halmozódását mutató tartósan munkanélküliek (180 napon túli álláskeresők) igen magas részaránya meglehetősen aggályos, éppen ezért külön figyelmet szentelek e gazdaságilag aktív korú csoport területi differenciálódására is. Habár a munkanélküliek nyilvántartott száma több szempontból (például módszertani sajátosságok, látens munkanélküliek stb.) árnyalhatja az egzakt munkaerőpiaci folyamatok megfigyelését (lásd Berde 2005), ennek ellenére számításainkban való alkalmazásuk kézzelfoghatóbb eredményekhez vezet.

A munkanélküliségi arány alacsonyabb térségi szinten (járás) történő jellemzésére a területi autokorrelációt alkalmaztam. A területi kutatások során ugyanis gyakran törekszünk arra, hogy a térben - a különböző ismérvek függvényében - valamilyen szabályszerűséget, illetve véletlenszerúséget fedezzünk fel. A regionális tudományban kitüntetett szerepe van a területi autokorrelációnak (Tóth 2003), mint térparaméteres elemzési eszköznek, és kíváló módszer a vizsgálandó jelenség - jelen kutatásban a munkanélküliségi arány paramétereinek területi eloszlására irányuló térbeli együttmozgások, egymásra hatások komplex vizualizálására, a munkanélküliség kontinuitásának, valamint szomszédsági viszonyainak feltárására.

\footnotetext{
${ }^{1} \mathrm{Ki}$ a munkanélküli? Az, aki az adott héten nem dolgozott és nincs is olyan munkája, amelyből átmenetileg hiányzott; a kikérdezést megelőző négy hét folyamán aktívan keresett munkát; két héten belül munkába tudott volna állni, ha talált volna megfelelő állást, vagy talált már munkát, ahol 90 napon belül dolgozni kezd (KSH 2018).

2 A munkanélküliségi arány a munkanélkülieknek a gazdaságilag aktív korú népességen belüli arányát jelöli (KSH 2018).
}

Területi Statisztika, 2020, 60(5): 517-547; DOI: 10.15196/TS600501 
A területi autokorreláció tehát megmutatja, hogy a vizsgált jelenség értéke mennyiben hasonlít, vagy éppen különbözik a szomszédjától. Míg szabályszerú elrendeződés, azaz pozitív autokorreláltság esetén az egymással szomszédos területekegységek értékei egymáshoz hasonlóak (magas-magas, alacsony-alacsony értékek egymásmellettisége), addig negatív autokorreláltság esetén éppen ellenkezőleg, az egymás mellett fekvő területek különböznek (alacsony-magas, magas-alacsony értékek) egymástól. Autokorrelálatlanság esetén a vizsgált jelenség értéke véletlenszerūen (nem szignifikáns) szóródik a térben (Tóth 2003, Dusek 2004).

Vizsgálatomban a Local Moran I alkalmazását, mint a lokális kifejezésre, a szomszédsági viszonyok feltárására alkalmas területi autokorrelációs eljárást vettem alapul, melynek számítása a következő (Moran 1948, Tóth 2003, Dusek 2004):

$$
I=\frac{N}{\sum_{i=1}^{N} \sum_{j=1}^{N} D_{i j}} \frac{\sum_{i=1}^{N} \sum_{j=1}^{N}\left(x_{i}-\bar{x}\right)\left(x_{j}-\bar{x}\right) D_{i j}}{\sum_{i=1}^{N}\left(x_{i}-\bar{x}\right)^{2}}
$$

ahol, $\left(\mathrm{x}_{\mathrm{i}}-\mathrm{x}\right)^{*}\left(\mathrm{x}_{\mathrm{j}}-\mathrm{x}\right)$ a területegységhez tartozó értékek és az átlagok különbségének a szorzata, a $\mathrm{D}_{\mathrm{ij}}$ a szomszédsági kapcsolatokat leíró mátrix egy általános eleme, $\mathrm{N}$ a területegységek száma.

A területi autokorreláció a következő tartományokban értelmezendő:

- I $>-1 /(\mathrm{N}-1)$, pozitív térbeli autokorreláció,

- $\mathrm{I}=-1 /(\mathrm{N}-1)$, nincs térbeli autokorreláció,

- $\quad \mathrm{I}<-1 /(\mathrm{N}-1)$, negatív térbeli autokorreláció.

A szomszédság meghatározásánál a vezérszomszédságot a 4 legközelebbi szomszéddal vettem figyelembe. A számításokat a GeoDa térinformatikai szoftver segítségével végeztem. A vizsgálat területi alapját a járás képezte. Mind az időbeli változásokból fakadó különbségek determinálására, mind az ezredfordulóra, mind 2017-re elkészítettem jelen elemzést (3. ábra).

A közfoglalkoztatás foglalkoztató hatásának meghatározásához a közfoglalkoztatásban eltöltött átlagos időtartamot ${ }^{3}$ vettem alapul a települési térfolyamatok differenciáinak kimutatására. ${ }^{4}$

A vizsgálat során a Központi Statisztikai Hivatal (KSH) (munkanélküliségi adatok), a Belügyminisztérium (közfoglalkoztatási adatok'5), továbbá a GeoX Térinformatikai Kft. Országos Területfejlesztési és Területrendezési Információs Rendszerben (TeIR) elérhetô (elérhetőségi adatok) adatbázisait használtam fel.

3 A közfoglalkoztatásban töltött átlagos időtartam számítása során az adott településen lakó közfoglalkoztatottak által ledolgozott napok nettó száma/30 hányadost alkalmaztam, százalékban kifejezve.

${ }^{4}$ A közfoglalkoztatás programtípusok (hosszú, országos, járási startmunka mintaprogramok) szerinti területi elemzés nem célja jelen tanulmánynak. Azonban említésre méltó, hogy az egyes programtípusokban részt vevők nem azonos súllyal szerepelnek. Továbbá, a programtípusok funkciójuk, reintegrációs hatásuk tekintetében jelentősen eltérhetnek (lásd például Alpek 2017).

5 A szerző ezúton is szeretné köszönetét kifejezni a Közfoglalkoztatási és Vízügyi Helyettes Államtitkárság munkatársainak az adatok rendelkezésre bocsátásáért.

Területi Statisztika, 2020, 60(5): 517-547; DOI: 10.15196/TS600501 


\section{A munkanélküliség területi jellemzöi és összefüggései}

A Lisszaboni Stratégia keretében megfogalmazott optimista európai uniós stratégia (Artner 2018) hazánk számára is merőben új munkaerőpiaci célkitúzéseket jelentett, mindenekelőtt a teljes foglalkoztatás felé történő elmozdulást. Ez a vízió az elmúlt programozási periódusban tovább erősödött. A Széchenyi 2020 stratégia részeként vállalt hazai foglalkoztatottsági növekedés (Európai Bizottság 2010) pozitív irányba mozdult el. Ennek ellenére, nem feledhető a több évtizede stabil belső egyenlőtlenségek alakulása, amely jelentősen árnyalja a makroszintű növekedést.

\section{Regionális, járási és települési szintư munkanélküliség}

Az ezredfordulótól a munkaerőpiaci periferialitást leginkább meghatározó munkanélküliség megoszlása területileg rendkívül különböző (1. ábra). Az országos átlagot jelentősen meghaladó munkanélküliségű régiók közül egyértelműen kiemelkedik Észak-Alföld, illetve Észak-Magyarország. Míg Észak-Alföldön az ezredfordulót követően a munkanélküliek száma lassan növekedett a 2008. évi világgazdasági válságig, addig Észak-Magyarországon fokozatosan mérséklődött egészen 2010-ig. A legtöbb munkanélküli egyértelmúen e két régióban koncentrálódik azóta is. A legkedvezőbb pozíciójú Nyugat-Dunántúl és Közép-Dunántúl, ahol a munkanélküliségi arány - a világgazdasági válságot követő évek kisebb-nagyobb hullámzásaitól eltekintve - viszonylag stabil. Szembetűnő Közép-Magyarország válságérzékeny helyzete, ahol a tömeges munkaerő-elbocsátások következtében mindössze 2014 után kezdett mérséklődni a munkanélküliek száma.

1. ábra

A regionális (NUTS 2) munkanélküliségi arány az országos átlag százalékában Regional (NUTS 2) unemployment rate as a percentage of the national average

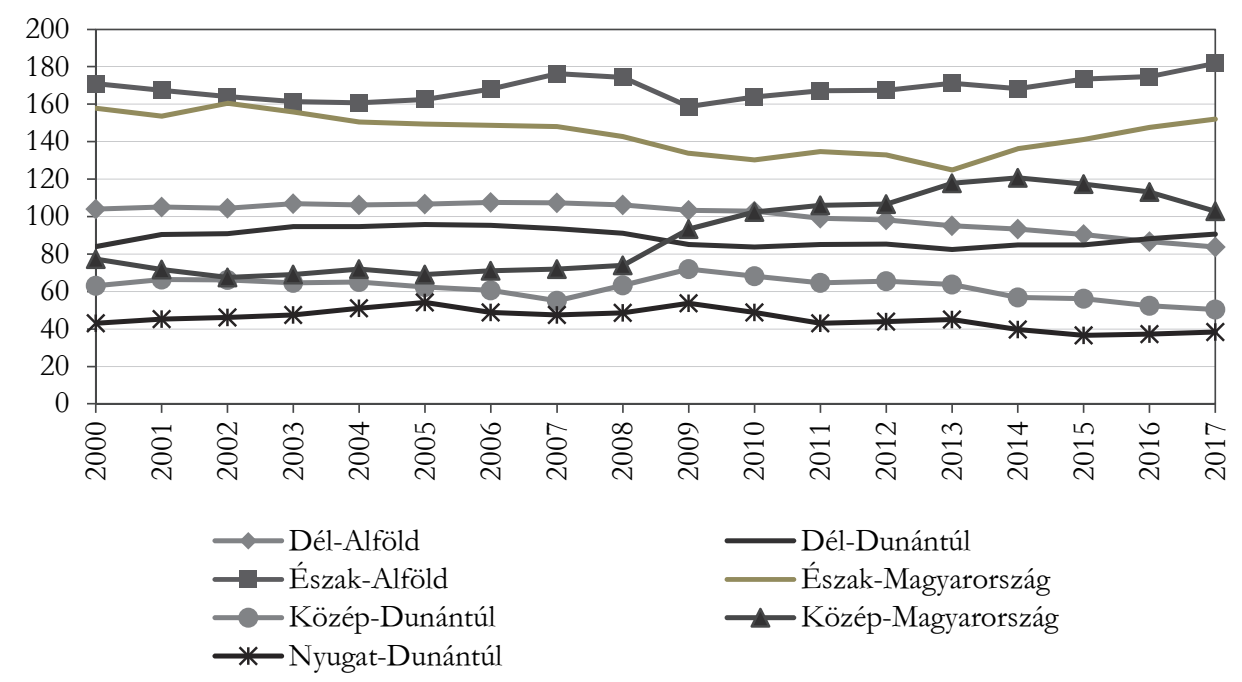

Területi Statisztika, 2020, 60(5): 517-547; DOI: 10.15196/TS600501 
Érdemes megvizsgálni a munkaerőpiaci elmaradottságot talán még pontosabban kifejező 180 napon túli, tartós munkanélküliségi arány (TMA) területi strukturálódását is (2. ábra).

2. ábra

A regionális (NUTS 2) TMA az országos átlag százalékában

Regional (NUTS 2) long-term unemployment rate as a percentage of the national average

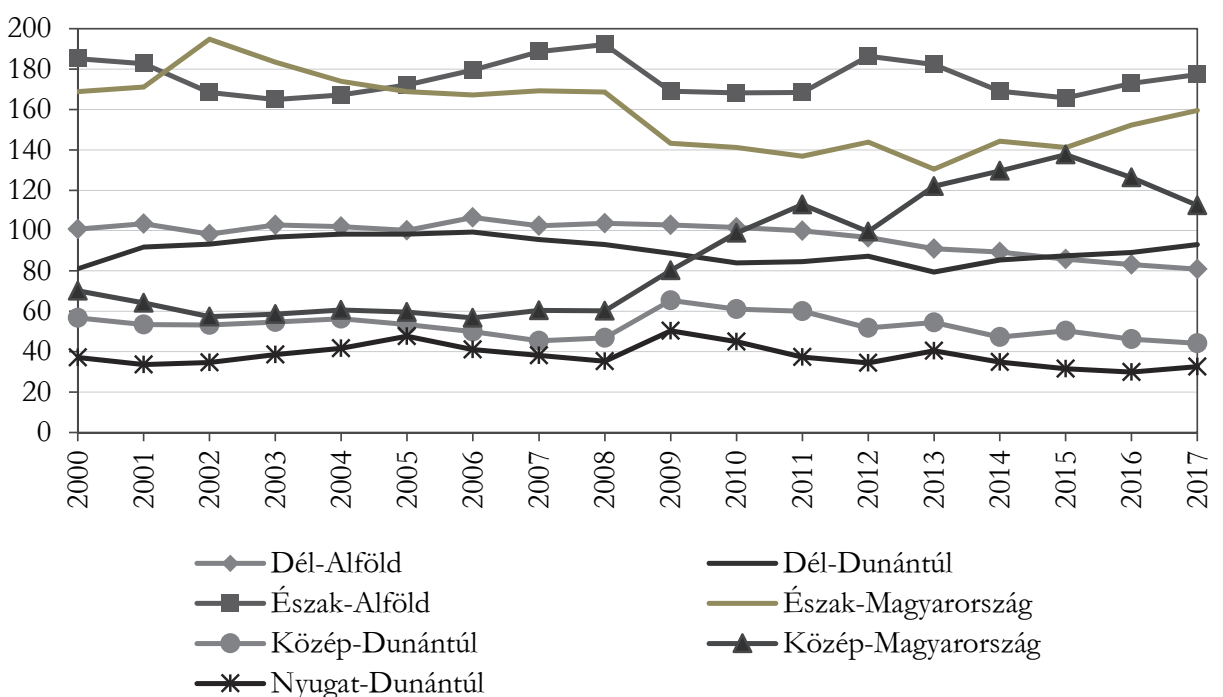

Forrás: A KSH adatai alapján saját szerkesztés.

A tartósan munkanélküliek koncentrálódása is egyértelműen Észak-Alföld, illetve Észak-Magyarország negatív munkaerőpiaci folyamatait jelzi. Míg előbbi kisebb hullámzásokat leszámítva viszonylag stabilan őrizte pozícióját, addig utóbbi a 2000-es évek eleji csúcsot (rendszerváltás okozta ipari leépülés, foglalkoztatottsági átrétegződés, lásd Pénzes 2013) követően 2013-ig fokozatosan mérséklődött, majd emelkedő tendenciájú, kiegészülve Észak-Alfölddel és Dél-Dunántúllal. A regionális megosztottságot jól jelzi, hogy az említett régiókon kívül zömében csökkent a tartósan munkanélküliek országos átlaghoz viszonyított aránya.

Összességében a makroszintű, dinamikus változékonyságot reprezentáló belső regionális munkanélküliségi tagoltság egyértelmúen rávilágít a hazánkban kumulálódó, erőteljes belső regionális divergens folyamatokra. Ezek alapján Magyarország „vesztes” térségeként egyértelműen kirajzolódik Észak-Alföld, Észak-Magyarország, illetve Dél-Dunántúl, szemben a pozíciójukat viszonylag stabilan őrző Nyugat- és Közép-Dunántúllal. Előbbi régiók periferikusságát jól mutatja, hogy Európa 20 legelmaradottabb régiói közé sorolhatóak (Eurostat 2017). A hazai fejlettségielmaradottsági térszerkezetet legkarakteresebben jellemző nyugat-kelet lejtő (lásd például Pénzes 2014, Győri-Mikle 2017) a tartósan munkanélküliek területi elhelyez-

Területi Statisztika, 2020, 60(5): 517-547; DOI: 10.15196/TS600501 
kedésében is megfigyelhető. A magas TMA területi koncentráltsága jelentős összefüggést mutat a roma etnikum területi szerkezetével (Európai Bizottság 2010, 2016). A tartós munkanélküliség legnagyobb arányban egyértelmúen a romákat sújtja (PásztorPénzes 2012). Okai között rendszerint az alacsony munkavállalási hajlandóságot, az iskolázatlanságot, továbbá a munkaerőpiaci diszkriminációt említik (Kertesi 2005).

A munkanélküliségi folyamatokat természetesen árnyalja, hogy alacsonyabb térségi szintre dezaggregált (járás) lokális értékek térfolyamataiban jelentős eltérések lehetnek. Felvetődik a kérdés, hogy a vizsgált járások - a munkanélküliségi arány tükrében - mennyire alkotnak elkülönülő klánokat? Ennek megragadására a módszertani fejezetben ismertetett területi autokorrelációt alkalmaztam.

3. ábra

A munkanélküliségi arány alapján számított (LAU1) területi autokorreláció

(LISA) eredménye, 2000, 2017

Result of territorial autocorrelation (LISA) calculated on the basis of the unemployment rate (LAU1), 2000, 2017

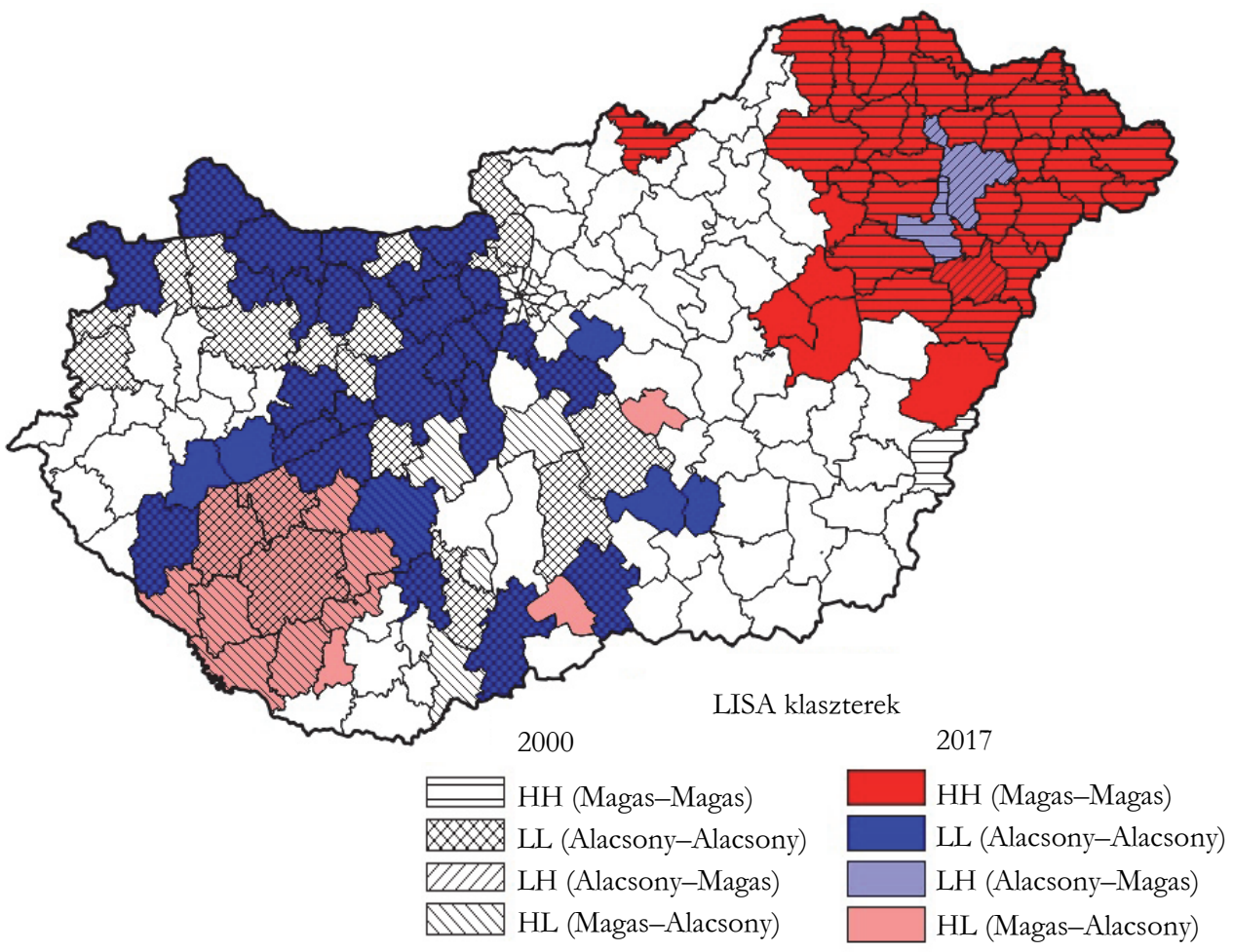

Nem szignifikáns

Megjegyzés: a számítás a 23 budapesti járás nélkül készült.

Forrás: A KSH adatai alapján saját számítás és szerkesztés.

Területi Statisztika, 2020, 60(5): 517-547; DOI: 10.15196/TS600501 
A munkanélküliségi arány járási szintre való dezaggregálása és két időpontra (2000, 2017) történő elemzése lehetővé teszi a lokális (járási) folyamatok területi eloszlásának, azaz a szomszédsági kapcsolatok, valamint az időbeli különbözőségből fakadó differenciák bemutatását.

Pozitív területi autokorreláltság, azaz a munkanélküliségi arány szabályszerú területi elrendeződése elsősorban Északkelet-Magyarországon (magas, illetve alacsony munkanélküliségi aránnyal jellemezhető járások szomszédságában is hasonlóan magasak, illetve alacsonyak az értékek) és a dunántúli járásokban (jóval heterogénebb eloszlást követve) figyelhető meg. Negatív területi autokorreláltság, azaz a szomszédos járások különböző értékeinek (alacsony-magas, magas-alacsony) koncentrálódása tipikusan Dél-Dunántúlon jelentkezett. Ezzel szemben a munkanélküliségi arány véletlenszerú területi eloszlása (autokorrelálatlanság) elsősorban a Duna-Tisza közén, illetve Zala, Vas és Veszprém megye egyes járásai esetében figyelhető meg.

A legkisebb munkanélküliségi arány az ország északnyugati peremén, elsősorban a Soproni járástól egészen a Szobi járásig, illetve a Szobi járástól egészen a Siófoki járásig tartó sávban koncentrálódott az ezredfordulón, kiegészülve néhány délalföldi járással, illetve az Esztergomi járástól egészen a Pécsváradi járásig kiterjedő, jellegzetes „J” alakot öltő tengelyével. Ehhez képest 2017-re 15 korábbi járás kikerült, míg 5 új járás (a Balaton északi partján - jelentôs idegenforgalmi övezetként ismert - Balatonfüredi és Tapolcai járás, valamint a kecskeméti autóipar foglalkoztató hatásait élvező Kiskunfélegyházi és Csongrádi járás) került be az alacsonyalacsony klaszterbe, azonban a területi eloszlásban nincs jelentős változás.

A legmagasabb munkanélküliségi arány - a vizsgált évek mindegyikében Északkelet-Magyarország járásaiban koncentrálódott, mintegy szigetként kiegészülve a Salgótarjáni járással. A hazánkban megfigyelhető munkaerőpiaci sérülékenységet jól mutatja, hogy a magas-magas klaszterbe került járások száma nemhogy csökkent volna, hanem nőtt, 6 további járással egészült ki. Mintegy megtörve a munkanélküliségi arány magas értékeinek kontinuitását, a Nyíregyházi és Debreceni járás kiemelkedett környezetéből az ezredfordulón, míg pozícióját meglepő módon a Nyíregyházi járás meg tudta ôrizni, amely alacsony értékeivel kitűnt a szomszédos magas értékekkel szemben, addig a Debreceni járás 2017-ben a magas-magas klaszterbe került. Ekkor mindössze a Hajdúböszörményi járás mutat egyértelmú javulást Északkelet-Magyarországon, magasabb foglalkoztatottságának köszönhetően. Ezzel szemben, míg az ország hasonló depresszív munkaerőpiaci tüneteket mutató déldunántúli járások esetében hasonlóan magas, addig az érintett járások egyes szomszédjai esetében leginkább alacsony a munkanélküliségi arány (magas-alacsony klaszter). Mindez a szomszédos járások kedvezőbb munkaerőpiaci folyamataira (például magasabb foglalkoztatottság és munkaerő-kereslet) enged következtetni, amely Északkelet-Magyarországhoz képest mindenképpen kedvezőbb a szomszédsági viszonyok tekintetében. Az ezredfordulón még alacsony-alacsony klaszterbe sorolható Kaposvári, Marcali és Fonyódi járás egytől egyig a magas-alacsony klasz-

Területi Statisztika, 2020, 60(5): 517-547; DOI: 10.15196/TS600501 
terbe kerültek 2017-ben (e járásokban a munkanélküliség alakulását jelentősen befolyásolják a Balaton szezonális idegenforgalmi hatásai). Továbbá szintén magas a munkanélküliségi arány - a szomszédos járásoktól szigetszerúen kiemelkedve - a Jánoshalmai, illetve a Nagykőrösi járásban.

A területi autokorrelációs vizsgálat 2000. és 2017. évi eredményei - a munkanélküliségi folyamatok kisebb volumenú változásaitól eltekintve - makroszintű stabilitást jelez. Ebből adódóan indokoltnak tartom, hogy a legsérülékenyebb munkaerőpiaci térségeket, azaz a legkarakteresebb munkanélküliségi aránnyal jellemezhetô településeket települési szinten is tipizáljuk az országos átlagot meghaladó értékek alapján.

\section{Az országos átlagot meghaladó munkanélküliségi arány tipizálásának települési strukturálódása}

Settlement structuring of the typology of the unemployment rate above the national average, 2000, 2009, 2018

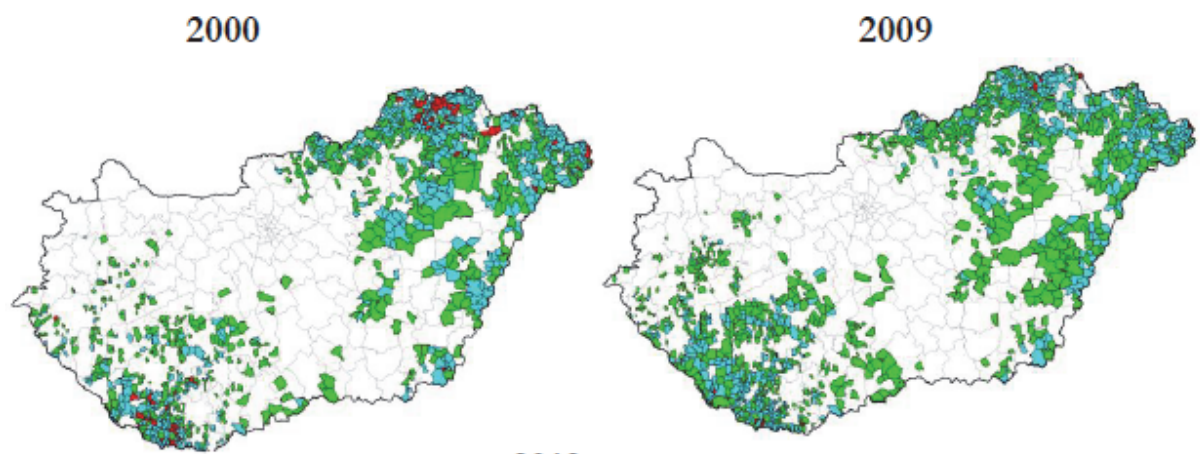

2018

4. ábra

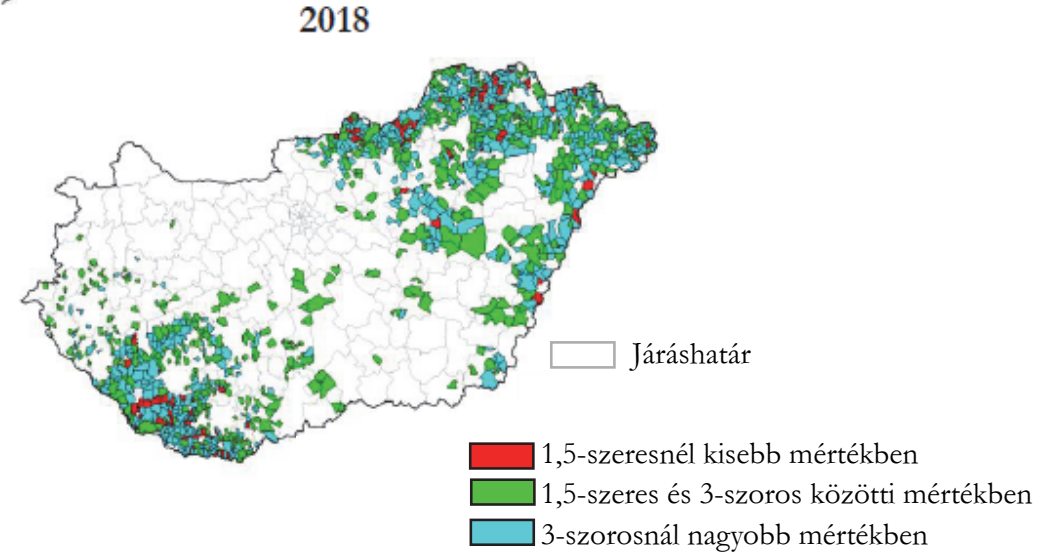

Megjegyzés: az adott évi települési kategóriákat a következőképpen alakítottam ki: a munkanélküliségi arány az országos átlagot 1,5-szeresnél kisebb, 1,5-szeres és 3-szoros közötti, valamint 3-szorosnál nagyobb mértékben haladja meg.

Forrás: A KSH adatai alapján saját szerkesztés. 
A munkanélküliségi arány települési térszerkezete szintén markáns stabilitást mutat az ezredfordulótól 2018-ig (4. ábra). Az országos átlagot is meghaladó munkanélküliségi arány karakterisztikus sűrűsödése Északkelet-Magyarországon (felülreprezentált a határ menti sáv, valamint a belső periferialitást mutató Közép-Tiszavidék), illetve a Dél-Dunántúlon (különösen Baranya megye déli határvonalában, valamint Somogy megye csaknem összes településén, Kaposvár vonzáskörzetét eltekintve) figyelhető meg. Az országos átlagot meghaladó munkanélküliségi klaszterek tekintetében tipikus települési klánok nem említhetőek (térségi heterogenitás), az országos átlagot 3-szorosan is meghaladó településektől eltekintve. Utóbbiak közül az ezredfordulón a Cserehát és térsége, valamint szórványosan Baranya megye déli részének települései emelkednek ki sérülékenységükkel. 2009-ben ez a klaszter mindössze 10 települést érintett, amely elsődleges oka a 2008. évi világgazdasági válság következtében kialakuló makroszintú emelkedés átlagos magas szintje. 2018ban - jellemzően a már előzőekben említett térségekben - ez a kategória 87 települést foglalt magában.

1. táblázat

\section{Az országos átlagot meghaladó munkanélküliségi arány alapján tipizált települések száma}

Number of settlements typified on the basis of the unemployment rate above the national average

\begin{tabular}{l|c|c|c}
\multicolumn{1}{c|}{ Típus } & 2000 & 2009 & 2018 \\
\hline $\begin{array}{l}\text { Az országos átlagot 1,5-szeresnél kisebb mértékben } \\
\text { meghaladó munkanélküliségi arány }\end{array}$ & 553 & 753 & 494 \\
$\begin{array}{l}\text { Az országos átlagot 1,5-szeres és 3-szoros közötti } \\
\text { mértékben meghaladó munkanélküliségi arány }\end{array}$ & 540 & 550 & 580 \\
$\begin{array}{l}\text { Az országos átlagot 3-szorosnál nagyobb mértékben } \\
\text { meghaladó munkanélküliségi arány }\end{array}$ & 76 & 10 & 87 \\
$\quad$ Összesen & 1169 & 1313 & 1161
\end{tabular}

Megjegyzés: az adott évi települési kategóriákat a következőképpen alakítottam ki: a munkanélküliségi arány az országos átlagot 1,5-szeresnél kisebb, 1,5-szeres és 3-szoros közötti, valamint 3-szorosnál nagyobb mértékben haladja meg.

Forrás: A KSH adatai alapján saját szerkesztés.

2000 és 2018 között az országos munkanélküliségi rátát 1,5-szeresnél kisebb mértékben meghaladó települések száma 59-cel csökkent, a 1,5-szeres és 3-szoros közötti mértékben meghaladó településeké 40-nel, illetve a 3-szorosnál nagyobb mértékben meghaladó településeké is 11-gyel emelkedett.

A regionális és a lokális területi, dinamikus elemzések egzaktan jellemzik a depresszív munkanélküliségú térségi és települési koncentrálódást: a térszerkezet stabilitást mutat 2018-ig, mindez a területi politika célzottságának, az erőforrások elosztásának hatékonysági megfelelősségére hívja fel a figyelmet. A munkanélküliségi arány és a TMA egyes településeken való „megmerevedésében” számos halmozódó faktor

Területi Statisztika, 2020, 60(5): 517-547; DOI: 10.15196/TS600501 
játszhat szerepet, mindenekelőtt az alacsony fokú képzettség (lásd LeaRn index Teperics et al. 2016), a településszerkezeti sajátosságokból fakadó településnagyság és a centrumoktól való távolságfaktor, a demográfiai folyamatok alakulása (Obádovics 2004), a ruralitás mértéke (Bódi-Obádovics 2000), a vállalkozási beágyazódás (Józsa 2017), az infrastrukturális fejlettség (Kőszegfalvi 2009) egyaránt stb. Jelen tanulmány a továbbiakban elsősorban a településszerkezeti sajátosságokra, azaz a településnagyságból fakadó különbözőségekre, illetve a centrumtérségektől való távolságfaktorra, valamint az iskolázottsági viszonyokra helyezi a fő hangsúlyt.

\section{A munkanélküliség és a településszerkezeti sajátosságok összefüggései}

A centralitás és ruralitás kérdésköre az egyre inkább élesedő - elsősorban a strukturális sajátosságokból fakadó - divergens folyamatok által átszôtt periferikus térségek leszakadásának megfékezése a jövőbeli munkaerőpiaci fellendülés egyik kulcskérdése. A következőkben a 2000., a 2010., a 2017. évi munkanélküliség és tartós munkanélküliség településnagyság szerinti klasztereződését, valamint az annak változásaiból fakadó dinamikus tényeket tárom fel (5. és 6. ábra).

5. ábra

\section{Munkanélküliségi arány a településnagyság szerinti klaszterek függvényében}

Unemployment rate as a function of clusters by settlement size

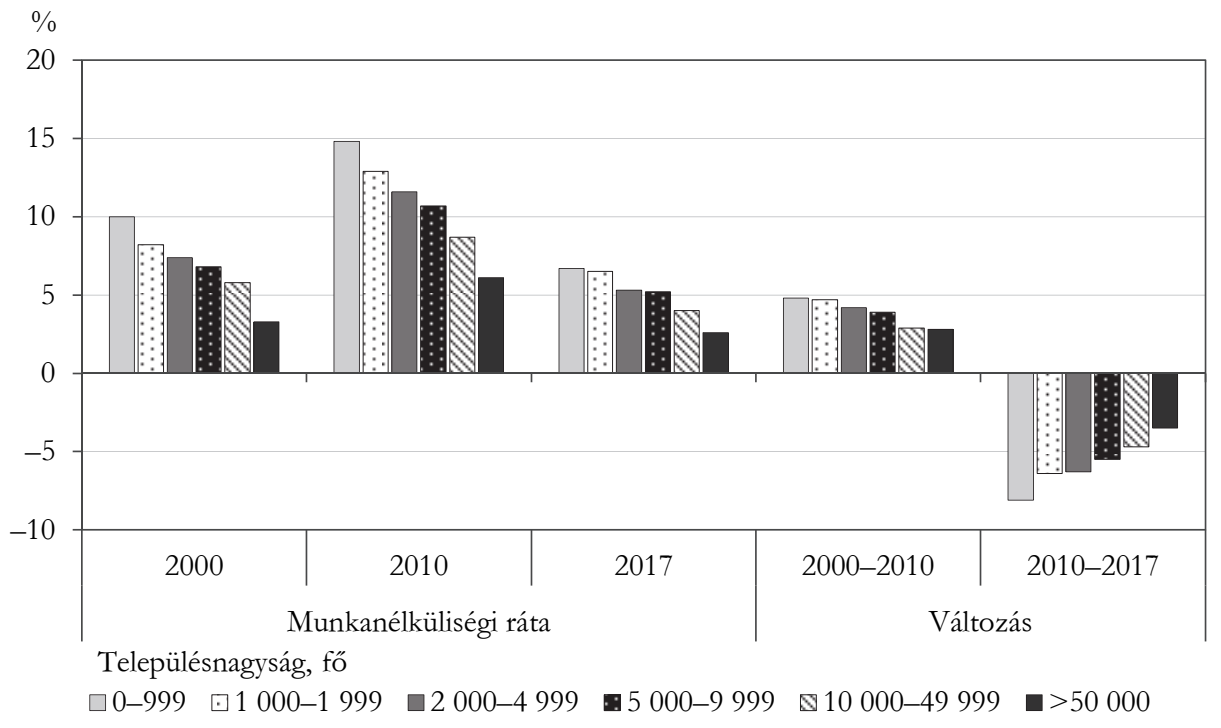

Forrás: A KSH adatai alapján saját szerkesztés.

A munkanélküliség településnagyság szerinti anomáliái rávilágítanak az országon belüli rurális jellegú települések periferialitására (5. és 6. ábra). A munkanélküliségi arány a településnagyság csökkenésével egyértelmúen egyre magasabb lett a vizsgált 
években. A legmagasabb munkanélküliségi arány - beleértve a tartós munkanélküliséget is - egyértelmúen az 1000, illetve 2000 főnél kevesebb lakosú községekben jellemző ${ }^{6}$. Másképpen fogalmazva, a város-vidék kettősség tovább fékezi az aktuális vidékfejlesztést. A 2008. évi világgazdasági válság következtében a munkanélküliség minden településnagyság esetében emelkedett. A legnagyobb mértékben az 50 ezer főnél is népesebb városokat sújtotta, ahol a 2000. évihez képest 2010-re a (tartós) munkanélküliség kvázi megduplázódott. Mindez összefügg a nagyvárosok tőkekoncentráltságával. Ugyanakkor a 2017. évi kedvezóbb helyzetet mutatja, hogy az összes településnagyság esetében csökkent a munkanélküliségi arány, amelyben mind a közfoglalkoztatás foglalkoztatást bővítő hatása, mind a decentrumokból történő munkaerőpiaci ingázás erőteljesebb térnyerése egyaránt feltételezhető. A vizsgált években a munkanélküliségi arány és a TMA között nincs éles különbség, legkisebb

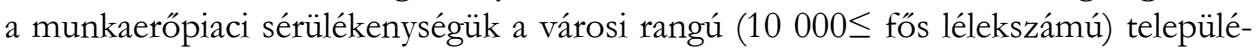
seknek.

6. ábra

TMA a településnagyság szerinti klaszterek függvényében

Long term unemployment rate as a function of clusters by settlement size

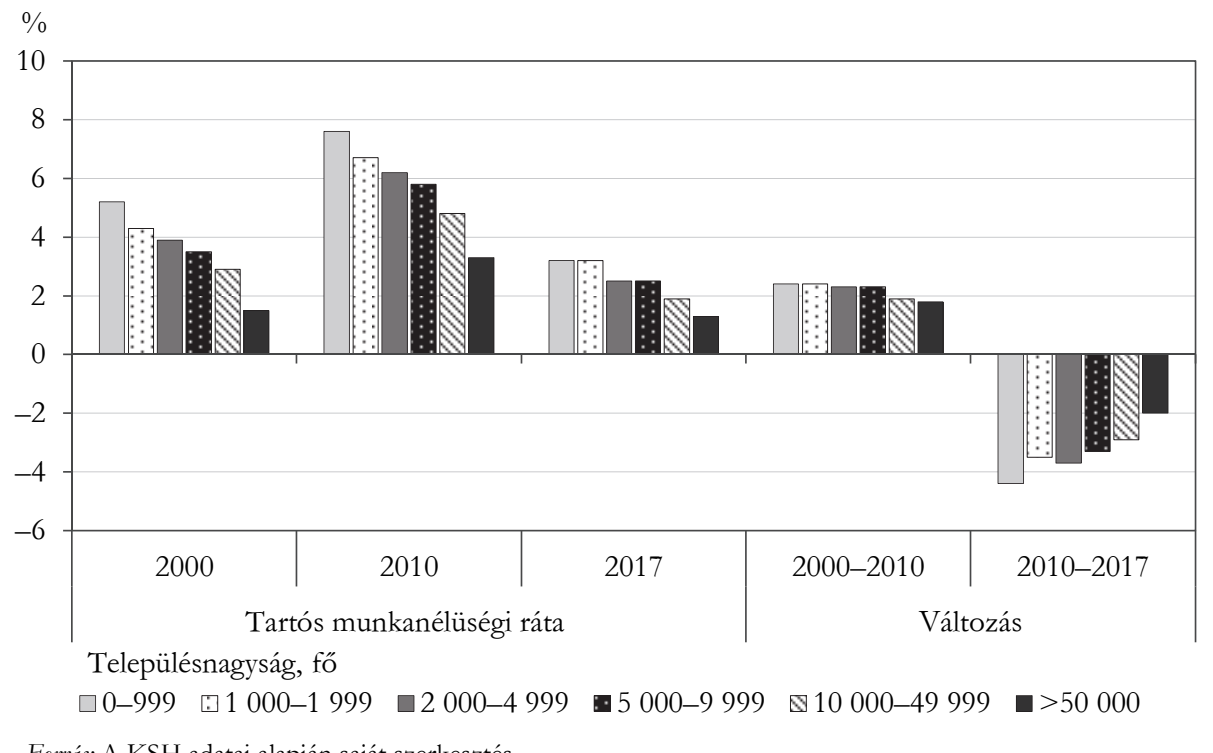

Forrás: A KSH adatai alapján saját szerkesztés.

Összességében megállapítható, hogy minél kisebb egy település, annál magasabb a munkanélküliségi rátája, amelyet korábbi vizsgálatok is alátámasztanak (BódiObádovics 2000). Habár 2010-hez képest jelentős csökkenés ment végbe, a legkisebb településeken élők foglalkoztatottsága továbbra is különösen alacsony, mely

${ }^{6} \mathrm{Ez}$ esetben fontos figyelembe venni azon településeket, ahol alacsony a gazdaságilag aktív korú népesség száma, melynek következtében az álláskeresői ráta némileg árnyalhatja az eredményeket.

Területi Statisztika, 2020, 60(5): 517-547; DOI: 10.15196/TS600501 
szoros összefüggést mutat a vonalas infrastruktúra (közúti elérhetőség) periferikus térségekbeli elmaradottságával (mobilitás ellehetetlenülése) (Kőszegfalvi 2009). Természetesen naivitás lenne azt feltételezni, hogy a legkisebb települések munkaerő-kereslete kielégítő lesz a lokális foglalkoztatottság jövőbeli növeléséhez. A nagyobb összefüggő zónát alkotó rurális terek legközelebbi központjainak (például a járásközpontok is) - vállalható ingázási távolságon belüli - munkahelyteremtési mechanizmusai ugyanakkor elengedhetetlenek.

A munkanélküliség magas, illetve alacsony koncentráltságának alakulását nagymértékben befolyásolja a centrumtelepülésektől való távolságfaktor, melynek mértéke jelentősen meghatározza a munkaerőpiaci ingázási relációkat, hajlandóságokat (Tésits-Alpek 2013), azaz a munkanélküliség alakulását (7. ábra).

7. ábra

A munkanélküliségi arány eltérése az országos átlagtól, a megyeszékhelyektől való távolságklaszterek függvényében

Unemployment rate deviation from the national average as a function of distance clusters from county seats

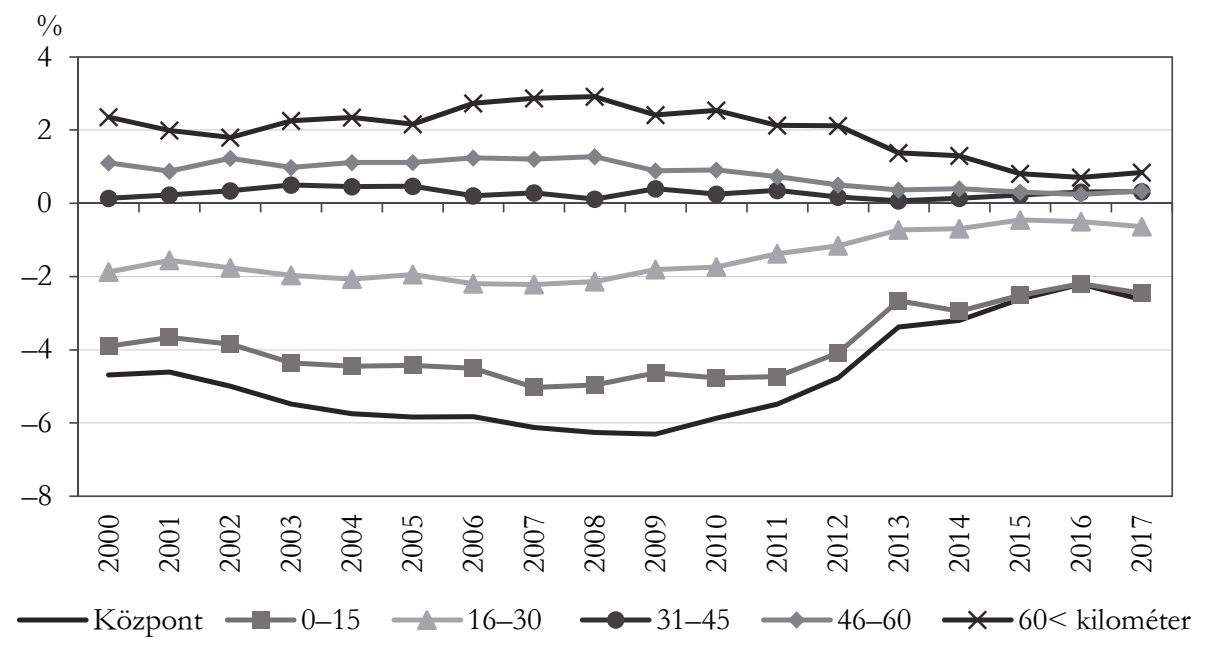

Forrás: A KSH és a GeoX Térinformatikai Kft. adatai alapján saját szerkesztés.

A legnagyobb foglalkoztatottsági erejű megyeszékhelyektől való távolsággal jellemezhető, fokozatosan emelkedő munkanélküliségi arány további aggályokra világít rá. A legkevesebb - az országos átlag alatti - munkanélküli a központi településeken élt a vizsgált időszakban, amely jól mutatja a centrumtelepülések kiemelkedő szerepét a hazai foglalkoztatottság alakulásában. A központoktól mért 15 kilométeres zónán belül fekvő települések kedvezőbb pozíciójára utal továbbá, hogy jelentős konvergencia figyelhető meg a központi településekkel, amely a szuburbanizáció kedvező településföldrajzi (centrumok rövid idôn belüli megközelíthetősége) és társadalmi (tehetôs, képzett emberi tôke nagyobb arányú jelenléte a szuburbán településeken) 
sajátosságára hívja fel a figyelmet (Dövényi-Kovács 1999). Országos átlag feletti munkanélküliségi aránnyal tendenciózusan a központoktól 30 kilométernél nagyobb távolságra található települések rendelkeznek, és az arány a távolság növekedésével exponenciálisan emelkedik. Ugyanakkor az is megállapítható, hogy a 31-45, illetve a 46-60 kilométeres távolsági zónában lakók munkanélkülisége a vizsgált időszak utolsó éveiben stagnál, s a 60 kilométernél távolabbi települések munkanélküliségi rátája mérséklődött.

\section{A TMA eltérése az országos átlagtól, a megyeszékhelyektől való távolságklaszterek függvényében}

Deviation of the long term unemployment rate from the national average as a function of distance clusters from county seats

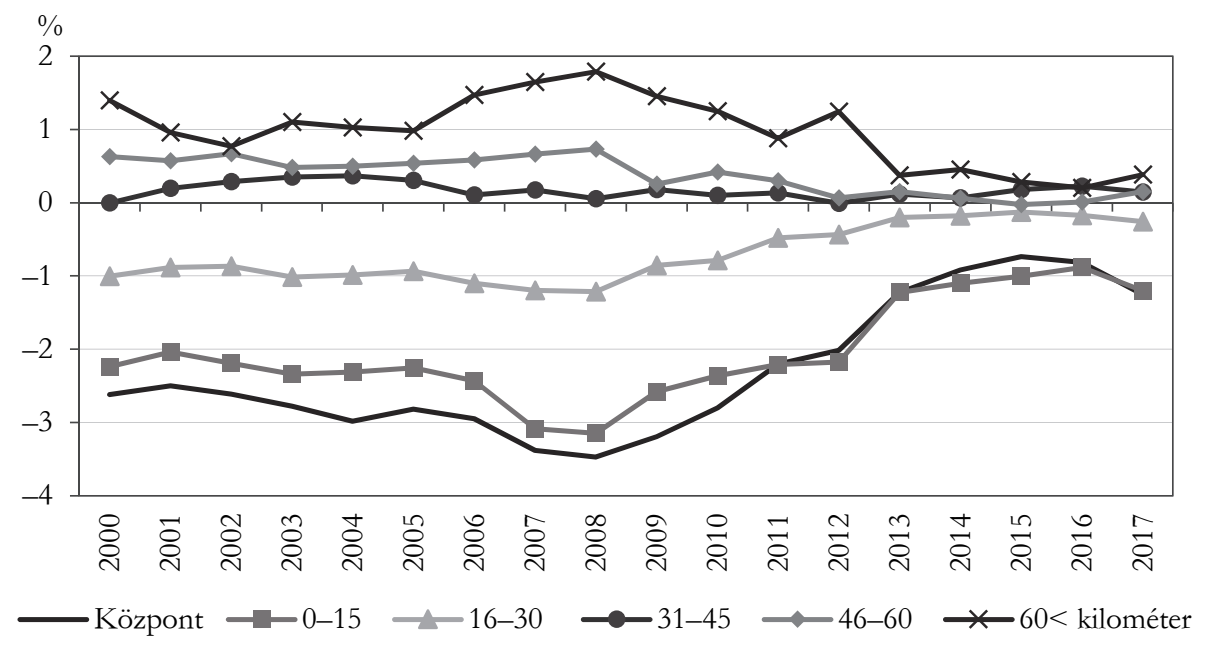

Forrás: A KSH és a GeoX Térinformatikai Kft. adatai alapján saját szerkesztés.

A TMA esetében hasonló tendenciák figyelhetôek meg (8. ábra). A központi, illetve a 0-15 kilométeres távolságon belül fekvő települések esetében még szorosabb az együtt mozgás, stabilan országos átlag alatti értékekkel. Kisebb, de az országos átlag alatti értékekkel rendelkeznek még a 16-30 kilométeren belül fekvő települések. Az e távolságkategórián felül fekvő települések - noha egyre kisebb aránnyal, de - az országos átlag feletti tartós munkanélküliséggel jellemezhetőek. A 2008. évi világgazdasági válság következményei a TMA esetében még élesebben megmutatkoznak. A központi és a 15 kilométeres zónán belül fekvő települések esetében érintette leginkább a munkaerőpiacról tartósan kiszorulókat, rátájuk mindössze 2016-tól kezdett mérséklődni.

Összességében megállapítható, hogy minél nagyobb távolságot kell megtenni a munkavállalóknak, annál nagyobb az immobilitás, amelyet a 2011. évi népszámlálási adatok eredményei is megerősítenek. A településeken belüli beingázás és elingázás aránya míg az elôbbiek esetében lényegesen kisebb és a magas foglalkoztatási rátájú

Területi Statisztika, 2020, 60(5): 517-547; DOI: 10.15196/TS600501 
centrumokba irányul, addig utóbbi mobilitási forma esetében a kisebb távolságú ingázásokat preferálják a munkavállalók (Bodor-Pénzes 2012, Kiss-Szalkai 2018). Ennek következtében a foglalkoztatási centrumoktól távol fekvő - a nem megfelelő szintű helyi munkaerőpiaci foglalkoztatás révén - települések mikrokörzetében megfigyelhető munkaerő-kereslet és -kínálat jelentősen meghatározza a munkanélküliség és a foglalkoztatottság alakulását.

\section{A közfoglalkoztatás szerepe és föbb összefüggései}

A hazai aktív munkaerőpiac-politikai intézkedések egyik legjelentősebb eszközének számító egységes közfoglalkoztatás - a 2011. évi reformoknak köszönhetően - jelentős szerepet játszott a világgazdasági válság utáni évek magas munkanélküliségi szintjének visszaszorításában. A közfoglalkoztatás magas arányú foglalkoztató hatásának kontinuitása egyes térségekben - főként a községek esetében - erôteljes beragadási hatást mutat, ugyanis egyes településeken elsődleges jövedelemszerzési forrásnak tekinthető (Kóti 2018). Mindebből fakadóan a közfoglalkoztatás interdiszciplinaritását igazolja, hogy foglalkoztatáspolitikai hatásmechanizmusain túlmenően megmutatkoznak mind a szociálpolitikai célokkal összefüggő hatásai (hátrányos helyzetűek foglalkoztatása), mind a vidék-, illetve területfejlesztési (munkahelyhiányos térségek előtérbe helyezése) - leginkább közvetetten érvényesülő hatásai (Váradi 2016, Gerő-Vígvári 2019).

\section{A közfoglalkoztatás föbb sajátosságai}

Tanulmányomban az egységes közfoglalkoztatás foglalkoztató hatását vizsgálom, rámutatva a makroszinten tapasztalható másodlagos munkaerőpiaci közfoglalkoztatás térnyerésének területi differenciáltságára, elsődleges szerepére. Elsősorban a rendelkezésre álló adatok függvényében - a 2014 és 2018 közötti időszakban - a térségi homogenitást, vagy éppen heterogenitást tükröző változásokat helyezem górcső alá. 
A közfoglalkoztatottak száma és a közfoglalkoztatási ráta régiók szerint Number of workfare employees and workfare employment rate by region

\begin{tabular}{|c|c|c|c|c|c|c|c|c|}
\hline \multirow[b]{2}{*}{ Régió } & \multicolumn{4}{|c|}{ Közfoglalkoztatottak száma, fő } & \multicolumn{4}{|c|}{ Közfoglalkoztatási rátaa), \% } \\
\hline & 2014 & 2016 & 2018 & $\begin{array}{c}\text { változás, } \\
2014- \\
2018\end{array}$ & 2014 & 2016 & 2018 & $\begin{array}{c}\text { változás }^{b} \text {, } \\
2014 \\
2018\end{array}$ \\
\hline Dél-Alföld & 27750 & 31315 & 19301 & -8449 & 3,6 & 3,8 & 2,3 & $-1,3$ \\
\hline Dél-Dunántúl & 23883 & 29394 & 16802 & -7081 & 4,4 & 4,9 & 2,9 & $-1,5$ \\
\hline Észak-Alföld & 56763 & 68986 & 45891 & -10872 & 6,2 & 6,9 & 4,7 & $-1,6$ \\
\hline Észak-Magyarország & 45186 & 51661 & 35438 & -9748 & 6,5 & 6,8 & 4,7 & $-1,8$ \\
\hline Közép-Dunántúl & 13001 & 12039 & 6274 & -6727 & 2,0 & 1,7 & 0,9 & $-1,1$ \\
\hline Közép-Magyarország & 13818 & 11245 & 5251 & -8566 & 0,8 & 0,6 & 0,3 & $-0,5$ \\
\hline Nyugat-Dunántúl & 9695 & 9565 & 5368 & -4327 & 1,6 & 1,4 & 0,8 & $-0,8$ \\
\hline Összesen & 190095 & 214204 & 134324 & -55770 & 3,2 & 3,3 & 2,1 & $-1,1$ \\
\hline
\end{tabular}

a) A közfoglalkoztatási ráta a közfoglalkoztatottak számát viszonyítja a közfoglalkoztatottak és a nyilvántartott álláskeresők létszámához.

b) Százalékpont.

Forrás: A Belügyminisztérium adatai alapján saját számítás és szerkesztés.

A közfoglalkoztatás foglalkoztató hatásának 3 különböző évét figyelembe vevő vizsgálat látszólag erőteljesen korrelál a magas munkanélküliséggel sújtott térségekkel (2. táblázat). Azaz, azokban a térségekben kumulálódik a legtöbb közfoglalkoztatott, ahol a legerôsebb, a depresszív munkaerôpiaci tünetek (például lásd magas arányú tartós munkanélküliség) koncentrálódnak: kiemelten Észak-Alföldön és Észak-Magyarországon. Az érme másik oldalát - a zömében jobb foglalkoztatási mutatókkal is rendelkező - Nyugat-, Közép-Dunántúl, illetve Közép-Magyarország jelentik, ahol az előző régióktól a közfoglalkoztatás foglalkoztató hatása jelentősen elmarad. A program 2016-ban érte el a csúcsát, mintegy 214204 fővel. Ezt követóen, a közfoglalkoztatás fokozatosan csökkenő tendenciát mutat, mintegy jelezve annak átmeneti foglalkoztató jellegét a magyar foglalkoztatáspolitikában. A legnagyobb (köz)foglalkoztatással jellemezhetô Észak-Alföldön és Észak-Magyarországon is jelentős a visszaesés 2014 és 2018 között. A közfoglalkoztatási ráta előbbiben 1,6, utóbbiban 1,8 százalékponttal csökkent. Megállapítható, hogy a közfoglalkoztatás foglalkoztató hatása az elmaradottabb munkaerőpiaci struktúrákkal jellemezhető térségekben is gyengült, melyben egyrészt jelentős szerepet játszott a kormányzat által egyre inkább előtérbe helyezett elsődleges célkitűzésből fakadó elsődleges munkaerőpiaci integráció, azaz a közfoglalkoztatásra fordítandó költségek fokozatos csökkentése, másrészt a vizsgált időszak végi gazdasági fejlődés révén erőteljesebb az elsődleges munkaerőpiac „szívóhatása” is.

Területi Statisztika, 2020, 60(5): 517-547; DOI: 10.15196/TS600501 
A közfoglalkoztatásban eltöltött átlagos időtartam* 2014-ben, illetve a 2014 és 2018 közötti változása, települések szerint

Average time spent in workfare employment in 2014 and its change between 2014 and 2018 by settlements

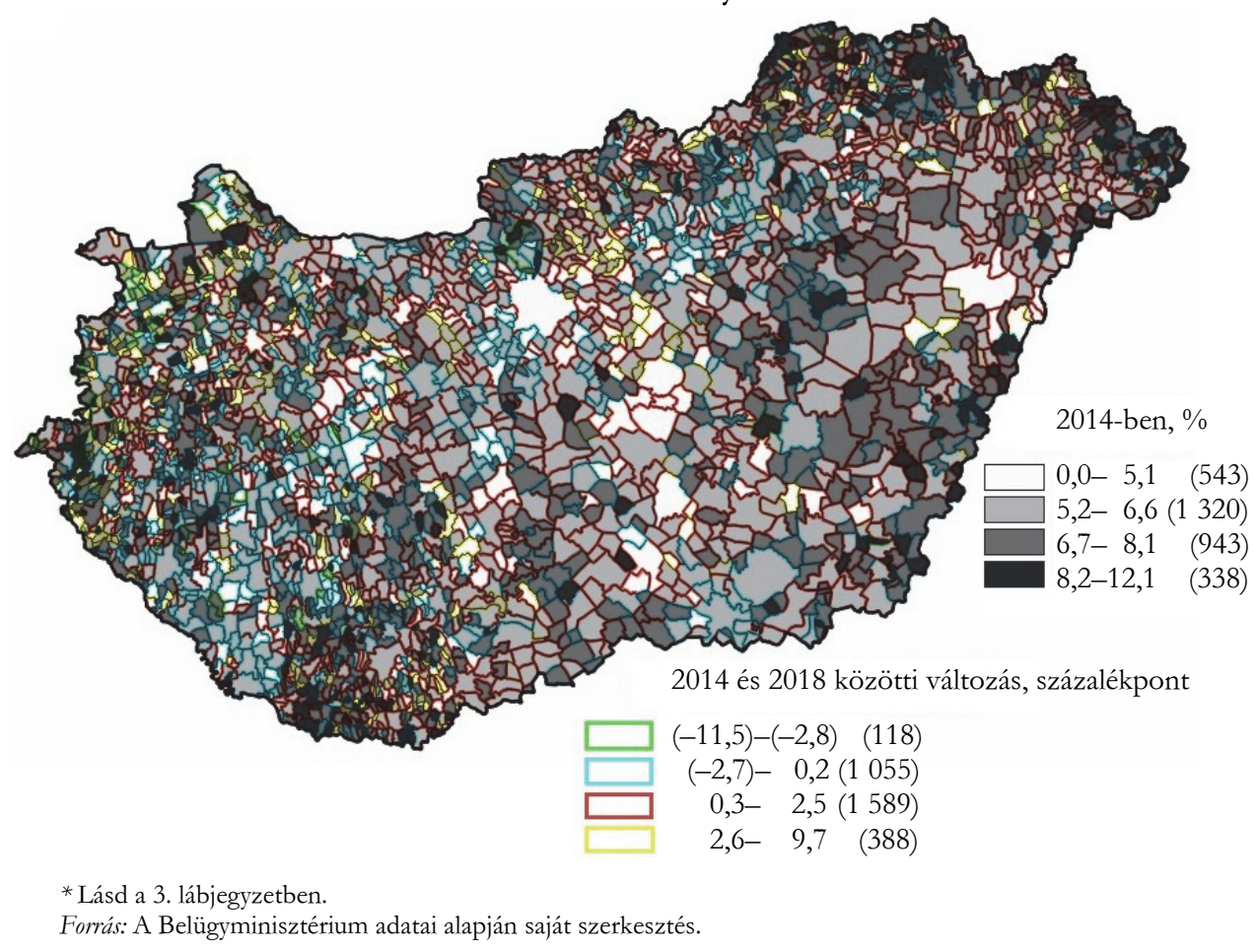

A teljes területi részletezettség érdekében a közfoglalkoztatás területi koncentráltságát egyaránt reprezentálni tudó közfoglalkoztatásban eltöltött átlagos időtartamot települési szintre dezaggregáltam, amely tovább részletezi a 2. táblázat regionális adatainak belső területi eloszlását. 2014-ben a leghosszabb közfoglalkoztatásban eltöltött idő a centrumtérségek vonzáskörzetéből leginkább kieső települések esetében vált meghatározóvá, ahol az elsődleges munkaerőpiaci kínálat nem tudott lépést tartani a gazdaságilag aktív korúak számával. A leghosszabb időtartamok a külső periferikus településeken koncentrálódtak, néhány belső periferikus térségben koncentrálódó településtől eltekintve (lásd Közép-Tisza-vidék). A leghosszabb idôtartamok 2014-ben Perecsén (12,1\%), Szijártóházán (11,8\%), Pusztaapátin (11,6\%) voltak, amelyet hasonló időtartamokkal a rurális jellegű települések sora követett. A 2018-ra történő változások sajátossága, hogy 2014-hez képest jelentősen csökkent a közfoglalkoztatást nem szervező önkormányzatok száma. 
Összességében 882 településen csökkent, 82 településen stagnált, míg 2186 településen növekvő tendenciát mutatott a közfoglalkoztatásban eltöltött időtartam 2014 és 2018 közötti változása. A legnagyobb emelkedés a következő településeken volt: Röjtökmuzsaj $(1,8 \%-11,4 \%)$, Tésa $(3,3 \%$ - 12,2\%), Zsebeháza $(3,0 \%$ 11,7\%), Baglad (3,8\% - 12,2\%) stb. Ennek okai: a hátrányos helyzetú munkavállalók nagy száma, a magas munkanélküliség, az alacsony mobilitási hajlandóság, a kormányzati források emelkedése, a programtípusok eltérô formái (helyi és helyzeti energiákhoz igazodó programtípusok) és funkciói (szociális funkció a közfoglalkoztatás által) (Hétfa Kutatóintézet 2018).

A közfoglalkoztatásban eltöltött átlagos időtartam térszerkezetét vizsgálva általánosságban megállapítható, hogy a közfoglalkoztatás foglalkoztató hatásának legjelentősebb csökkenése a Nyugat-Magyarország határ menti, zömében rurális településeket magában foglaló sávban koncentrálódott, ahol egyaránt megfigyelhető volt egyes települések jelentős pozitív irányú növekedése is. A változás mindenekelőtt azt mutatja, hogy a közfoglalkoztatás a foglalkoztatáspolitika szerves részét képezi a jobb gazdasági feltételek (széles körû munkahelykínálat) ellenére is, esélyt teremtve a hátrányos helyzetű munkavállalók munka világába való bekapcsolódására.

A legjelentősebb munkaerôpiaci depresszióval küzdő térségek számára (lásd komplex programmal fejlesztendő járások) nagymértékű a forrásátcsoportosítás, jelezve ezen térségek közfoglalkoztatástól való függőségét, azzal szoros kapcsolatát. Az e településeken élő (főként a magas koncentráltságú közfoglalkoztatású térségekben) hátrányos helyzetű munkavállalók elsődleges munkaerőpiaci integrációját, foglalkoztathatóságát, a jövőbeli munkaerő-szükséglet kielégitését: mindenekelőtt a település munkaerőpiaci környezete (például tőkevonzó képesség), a mobilitási hajlandóság, az emberierőforrás-fejlettség és -fejlesztési gyakorlat jelentősen meghatározzák.

\section{A munkanélküliség, a közfoglalkoztatás és az iskolázottság összefüggései}

A klasszikus telephelyelméletek változásával, háttérbe szorulásával megváltozott a centrális és a periferikus térségek koncentráltságát-dekoncentráltságát előtérbe, illetve háttérbe szorítani tudó tényezők köre. Napjainkban a regionális politika fő mozgatórugóját megkérdőjelezhetetlenül a tőkemozgások uralják (Nemes Nagy 2005). A globalizáció világában a posztindusztriális gazdaság előtérbe kerülésével a piaci szereplők telephelyválasztásában megváltoztak a területi versenyelőnyök. Az egyik legfontosabb versenyképességi faktort a tudásalapú társadalom, azaz a megfelelő mennyiségú és minőségű emberi erőforrás megléte jelenti (Lengyel 2006).

Ennek keretében nem elvetendő a versenyszféra potenciális munkaerőigényét kielégíthető munkanélküliek és közfoglalkoztatottak iskolázottsági szintjének meghatározása, valamint a munkaerőpiaci státus és a képzettség közötti összefüggések vizsgálata.

Területi Statisztika, 2020, 60(5): 517-547; DOI: 10.15196/TS600501 
A munkanélküliek legmagasabb iskolai végzettség szerinti területi differenciálódása, a munkanélküliek arányában, 2018

Territorial differentiation of the unemployed according to the highest level of education, in the proportion of the unemployed, 2018, \%

Legfeljebb 8 általános iskola Maximum primary school

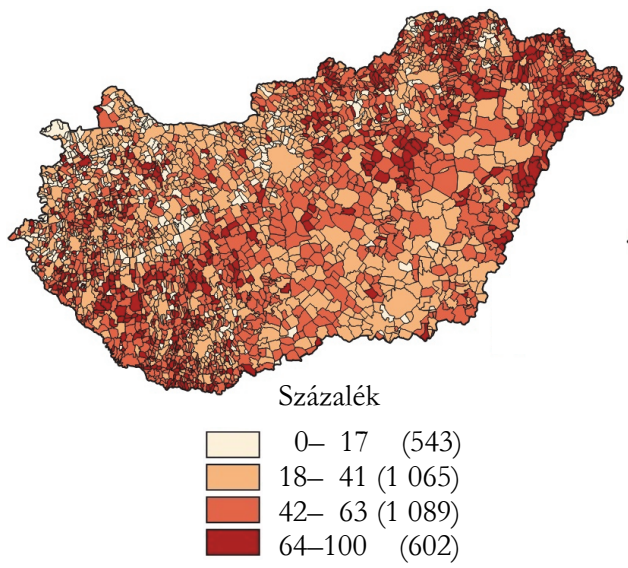

Szakközépiskola, gimnázium, technikum

Vocational secondary school, grammar school, technical school

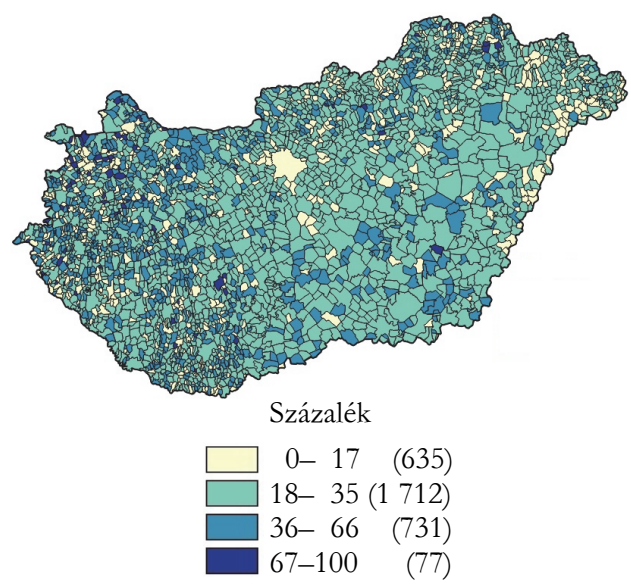

Forrás: A KSH adatai alapján saját szerkesztés.
Szakiskola, szakmunkásképző Vocational school, vocational training

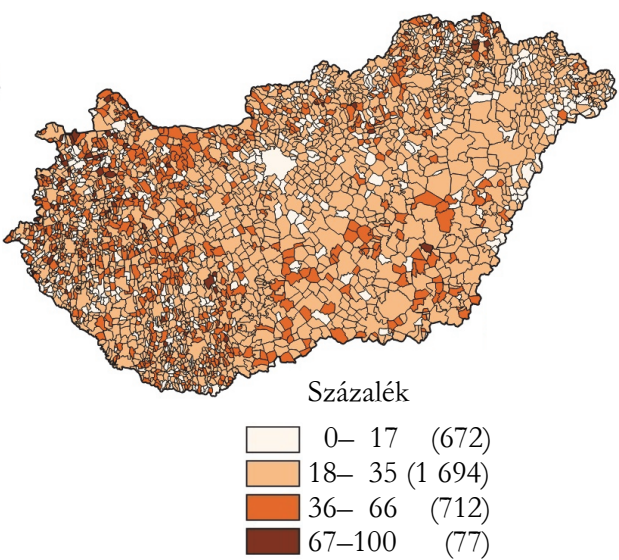

Főiskola, egyetem

College, university

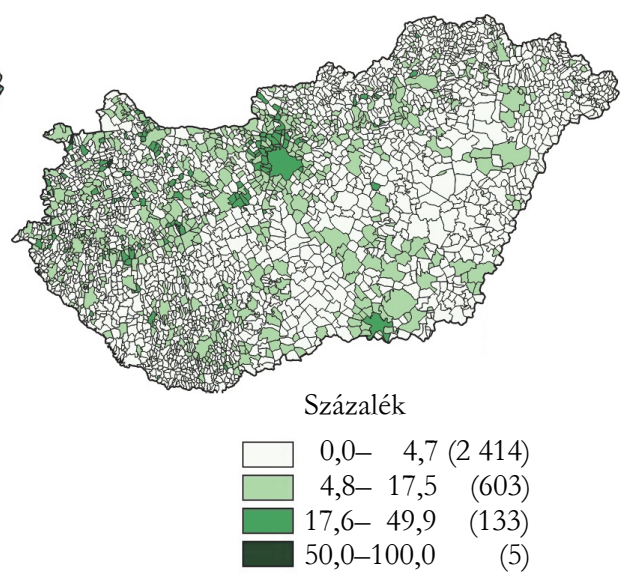


A legtöbb legfeljebb 8 általános iskolai végzettségú munkanélküli (10. ábra) Északkelet-Magyarországon, különösen a határ menti térségekben és a karakterisztikusan kirajzolódó belső periféria esetében, illetve Dél-Dunántúlon csúcsosodott ki 2018-ban. A középfokú végzettség tekintetében korántsem egyértelmú a területi strukturálódás. Sokkal dekoncentráltabb a munkanélküliek megoszlása a szakiskolával, szakmunkásképzővel és szakközépiskolával, gimnáziummal vagy technikummal rendelkezők körében. Ugyanakkor az is jól kirajzolódik, hogy a középfokú végzettségű munkanélküliek aránya ott nagyobb, ahol az elsődleges munkaerőpiaci elvárások egyértelmúen magasabb tudástőkét igényelnek, lásd azon nyugat-magyarországi településeket, ahol tendenciózusan a középfokú végzettség sem minősül elegendőnek az elsődleges munkaerôpiaci elvárásokhoz. Mindezt alátámasztja a felsőfokú végzettséggel rendelkező munkanélküliek területi eloszlása. Egyrészt a fejlettebb településeken figyelhető meg a legtöbb diplomás álláskereső, ahol az ország legtöbb elvégzett átlagos osztályszáma kumulálódik (Pénzes et al. 2018). Másrészt, a diplomás munkanélküliek számának alakulását nagyban meghatározza az adott térség felsőfokú végzettséget igénylő munkaerő-kereslete (Kertesi-Köllő 2006). Kiemelhető a Budapest-Szeged, illetve Budapest-Győr-Sopron tengely. Ugyanakkor megállapítható, hogy 2018-ban a munkanélküliek legmagasabb részarányát egyértelmúen a legfeljebb 8 általános iskolával rendelkezők alkotják, szemben a főiskolával, egyetemmel rendelkezőkkel. Mindez a magasfokú iskolázottság munkavállalási esélyeinek elsődleges munkaerőpiaci koherenciáira, kedvezőbb helyzetére hívja fel a figyelmet.

A másodlagos munkaerôpiaci szereplők eltérő helyzetértékelését mutatja, hogy zömében azon gazdaságilag aktív korúak vesznek részt a rendszerben, akik - alacsony iskolai végzettségük miatt - kevésbé felelnek meg az elsődleges munkaerópiac elvárásainak, ami a közfoglalkoztatásban való beragadás egyik legfőbb alakítója (Cseres-Gergely-Molnár 2014, Kóti 2018).

A hazai munkaerőhiány megszüntetése szempontjából aggályos, hogy a legtöbb közfoglalkoztatott - talán nem meglepő módon - legfeljebb 8 általános iskolai végzettséggel rendelkezik (11. ábra), ami a munkaadók foglalkoztatási hajlandóságát kérdőjelezi meg. A legfeljebb 8 általános iskolai végzettséggel rendelkező álláskeresők közel azonos aránnyal szerepelnek a közfoglalkoztatottak összvolumenében országosan, jelentéktelen területi különbséggel. A legmagasabb részarány sorrendben: Somogy (69\%), Heves (61\%), Borsod-Abaúj-Zemplén (61\%) és SzabolcsSzatmár-Bereg megyében $(60 \%)$ figyelhető meg. A középfokú végzettséggel rendelkező közfoglalkoztatottak szintén közel azonos arányban oszlanak meg az ország területén, szintén jelentősebb koncentrációk nélkül. Például az éllovas Békés megyében a közfoglalkoztatottak 51\%-át adják a középfokú végzettséggel rendelkezők, amely az elsődleges munkaerôpiac foglalkoztatási hajlandóságát is pozitívan befolyásolhatná, ennek ellenére itt is erős beragadási hatások érzékelhetőek, a létszámadatok alapján. A felsőfokú végzettséggel rendelkező közfoglalkoztatottak területi megoszlásában is jelentős homogenitás figyelhető meg. A legtöbb diplomás közfoglal-

Területi Statisztika, 2020, 60(5): 517-547; DOI: 10.15196/TS600501 
koztatott a fejlettebb térségekben: Pest (6\%), Győr-Moson-Sopron (4\%), Csongrád (4\%) és Komárom-Esztergom (2,4\%) megyében koncentrálódott.

A közfoglalkoztatottak számának és legmagasabb iskolai végzettségének területi megoszlása, 2018

Distribution of workfare employees by territorial unit and highest educational attainment, 2018

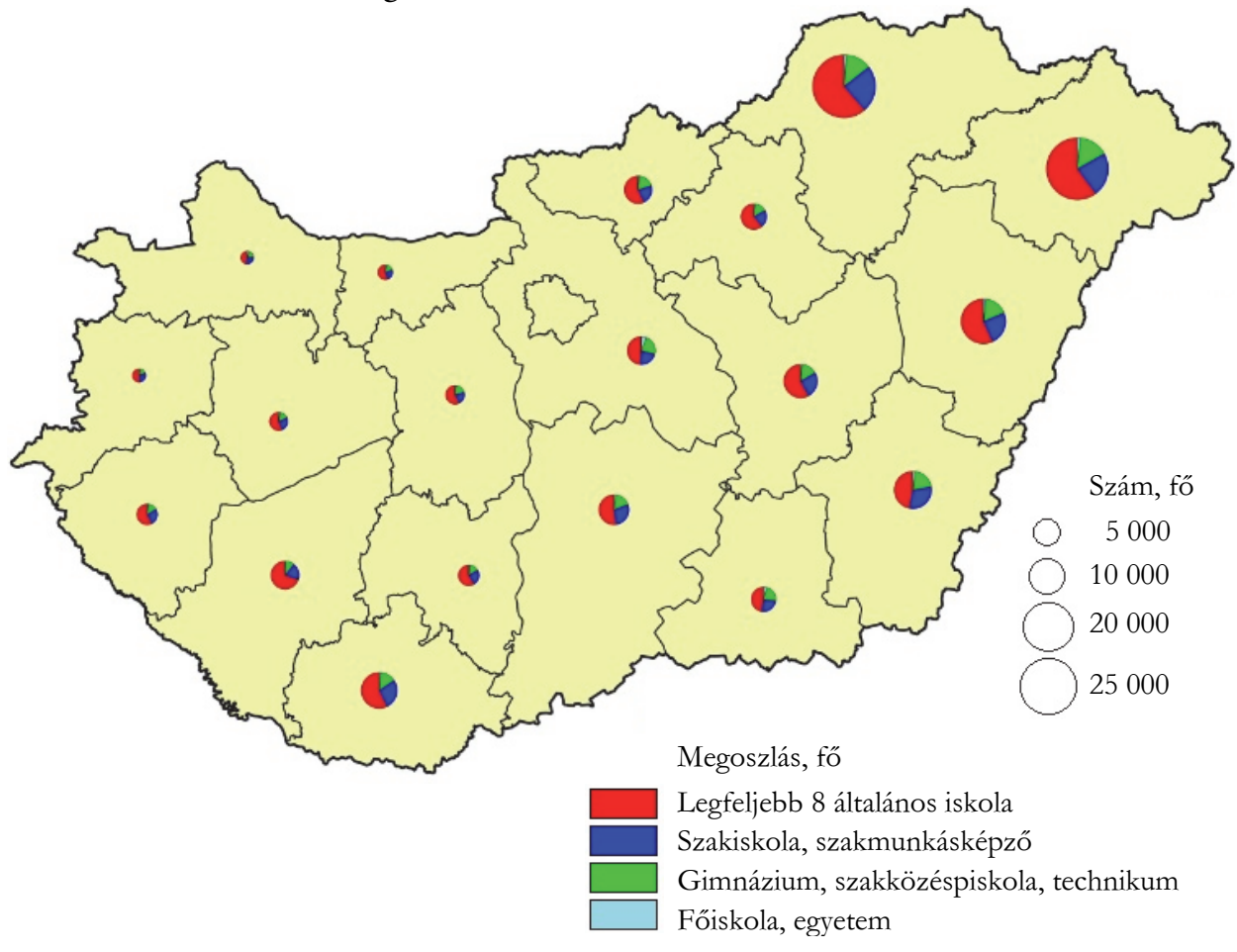

Forrás: a Belügyminisztérium adatai alapján saját szerkesztés.

A közfoglalkoztatottak elsődleges munkaerőpiaci (re)integrációját - ahogyan már utaltam rá - jelentősen meghatározza legmagasabb iskolai végzettségük, ebből adódóan érdemes áttekinteni az időbeli változásokból fakadó különbségeket is. 
3. táblázat

A közfoglalkoztatottak iskolai végzettségének regionális megoszlása

Distribution of workfare employees by educational attainment by regional breakdown

\begin{tabular}{|c|c|c|c|c|}
\hline Megnevezés & $\begin{array}{c}\text { Legfeljebb } \\
8 \text { általános iskola }\end{array}$ & $\begin{array}{c}\text { Szakiskola, } \\
\text { szakmunkásképző }\end{array}$ & $\begin{array}{l}\text { Gimnázium, } \\
\text { szakközépiskola, } \\
\text { technikum }\end{array}$ & Főiskola, egyetem \\
\hline & \multicolumn{4}{|c|}{ Dél-Alföld } \\
\hline 2014 & 47,0 & 31,0 & 19,3 & 2,7 \\
\hline 2018 & 48,8 & 29,2 & 19,9 & 2,2 \\
\hline \multirow{2}{*}{ Változása) } & 1,8 & $-1,8$ & 0,6 & $-0,5$ \\
\hline & \multicolumn{4}{|c|}{ Dél-Dunántúl } \\
\hline 2014 & 56,6 & 27,7 & 13,9 & 1,8 \\
\hline 2018 & 61,5 & 24,5 & 12,8 & 1,2 \\
\hline \multirow[t]{2}{*}{ Változása) } & 4,9 & $-3,2$ & $-1,1$ & $-0,6$ \\
\hline & \multicolumn{4}{|c|}{ Észak-Alföld } \\
\hline 2014 & 55,6 & 25,7 & 16,7 & 1,9 \\
\hline 2018 & 58,9 & 23,9 & 15,8 & 1,5 \\
\hline \multirow[t]{2}{*}{ Változása) } & 3,3 & $-1,8$ & $-0,9$ & $-0,4$ \\
\hline & \multicolumn{4}{|c|}{ Észak-Magyarország } \\
\hline 2014 & 57,3 & 26,1 & 15,1 & 1,5 \\
\hline 2018 & 60,8 & 23,7 & 14,3 & 1,2 \\
\hline \multirow[t]{2}{*}{ Változása) } & 3,5 & $-2,4$ & $-0,8$ & $-0,3$ \\
\hline & \multicolumn{4}{|c|}{ Közép-Dunántúl } \\
\hline 2014 & 52,4 & 28,6 & 16,4 & 2,6 \\
\hline 2018 & 56,5 & 24,2 & 17,0 & 2,2 \\
\hline \multirow[t]{2}{*}{ Változása) } & 4,1 & $-4,4$ & 0,6 & $-0,4$ \\
\hline & \multicolumn{4}{|c|}{ Közép-Magyarország } \\
\hline 2014 & 48,6 & 23,0 & 23,1 & 5,3 \\
\hline 2018 & 49,0 & 21,9 & 23,0 & 6,0 \\
\hline \multirow[t]{2}{*}{ Változása) } & 0,4 & $-1,1$ & $-0,1$ & 0,7 \\
\hline & \multicolumn{4}{|c|}{ Nyugat-Dunántúl } \\
\hline 2014 & 49,9 & 29,2 & 17,8 & 3,2 \\
\hline 2018 & 54,2 & 27,8 & 15,6 & 2,3 \\
\hline Változása) & 4,3 & $-1,4$ & $-2,2$ & $-0,9$ \\
\hline
\end{tabular}

Ahogyan a 11. ábra mutatja, a legmagasabb iskolai végzettség tekintetében a legnagyobb a legfeljebb 8 általános iskolai végzettséggel rendelkezók aránya, amely mindenképpen negatívan hat a versenyszféra munkaerôpiacára történő (re)integrációra. Sőt, arányuk 2014 és 2018 között az egész országban nőtt. A leghát-

Területi Statisztika, 2020, 60(5): 517-547; DOI: 10.15196/TS600501 
rányosabb helyzetű térségeket magában foglaló Dél-Dunántúlon, Észak-Alföldön és Észak-Magyarországon volt legjelentősebb a növekedés, illetve a kedvezőbb fejlettségi pozíciót elfoglaló Nyugat-Dunántúlon. A közfoglalkoztatottak második legnagyobb csoportját képezik a szakiskolával, szakmunkásképzővel rendelkezők, 2018-ra fokozatos mérséklődést mutatva. Az érettségivel és a diplomával ${ }^{7}$ rendelkezők részaránya csökkent, amelyben jelentős szerepet játszhat a munkaadók kedvezőbb megitélése, foglalkoztatási hajlandósága és szerepköre.

Az emberierőforrás-fejlesztés napjaink területfejlesztésben betöltött lényeges szerepkörének, beavatkozásainak ellenére is jelentôs azon aktív korúak száma, akik foglalkoztathatóságát elsősorban az alacsony iskolai végzettség, a szükséges munkakompetenciák hiánya lehetetleníti el (Hétfa Kutatóintézet 2018).

\section{Összefoglalás, konklúziók}

Tanulmányomban feltártam a munkanélküliség és a közfoglalkoztatás hazai alakulását, területi különbségeit és összefüggéseit. Az elsődleges fókuszt a munkanélküliség - beleértve a tartós munkanélküliség regionális és lokális beágyazódásának strukturálódásából fakadó belső különbségek nyomon követését, az azt alakító településszerkezeti feltárásokat, a közfoglalkoztatás foglalkoztatottsági hatásának feltérképezését -, illetve a munkanélküliség és a közfoglalkoztatás iskolázottsági összefüggéseinek vizsgálatai jelentették, amelyből a következők állapíthatók meg:

- A munkanélküliség dinamikus változékonyságát figyelembe vevő vizsgálat a legelmaradottabb és a legfejlettebb térségekben egyértelmú stabilitást mutat az ezredfordulótól kezdődően. A régiók közül míg Észak-Alföld, ÉszakMagyarország és Dél-Dunántúl periferikus karaktere révén, addig Nyugat- és Közép-Magyarország, illetve Közép-Dunántúl egyre kedvezőbb pozíciójával emelkedik ki.

- A települési szintre dezaggregált számítások alapján egyes térségeknek tartósan az országos átlag feletti volt a munkanélküliségi rátájuk a vizsgált időszakban: jelentős munkaerőpiaci sérülékenységgel jellemezhető ÉszakkeletMagyarország (különösen a külső periferikus határ menti sáv, illetve a karakterisztikusan kirajzolódó belső perifériás jegyeket hordozó Közép-Tiszavidék) és Dél-Dunántúl (kiemelten Somogy megye, továbbá Baranya megye déli határvonala) csaknem egész területe.

- A településnagyság és a legközelebbi centrumtelepülésektől való távolságfaktor egyértelmúen determinálja a munkanélküliség területi alakulását. Megállapítható, hogy minél kisebb egy település, illetve minél messzebb helyezkedik el a centrumoktól (jelen vizsgálatban megyeszékhelyek), annál magasabb a munkanélkülisége, mind a munkanélküliségi rátája, mind a tartós munkanélküliségi rátája.

7 A diplomával rendelkező közfoglalkoztatottak jelentős része a magasabb iskolai végzettséget, képzettséget igénylő országos közfoglalkoztatási programon belüli (például kulturális közfoglalkoztatás) feladatokat lát el, ahol megkívánják a magasabb tudástőkét.

Területi Statisztika, 2020, 60(5): 517-547; DOI: 10.15196/TS600501 
- A munkanélküliség csökkentésére, az elsődleges munkaerőpiaci (re)integrációra irányuló hazai közfoglalkoztatás egyes településeken jelentősen felülreprezentált. A legtöbb közfoglalkoztatott azokban a térségekben koncentrálódik, ahol a munkaerő-kereslet leginkább alulmarad a munkanélküliek és a közfoglalkoztatottak számához képest. Mindez a közfoglalkoztatásban való beragadási hatást erősíti.

- A munkanélküliek legmagasabb iskolai végzettség szerinti vizsgálatával szintén további összefüggések állapíthatók meg. A legtöbb legfeljebb 8 általános iskolai végzettséggel rendelkező munkanélküli magas korrelációt mutat a munkanélküliségi aránnyal. Azaz, az alacsony iskolai végzettség szervesen hozzájárul a munka világától való tartós távolmaradáshoz, amely elsődlegesen a munkaerőpiaci elvárásoknak való meg nem feleléssel magyarázható.

- A közfoglalkoztatás - célorientáltsága révén (hátrányos helyzetűekre való fókuszálás) - elsősorban az alacsonyabb tudástôkével rendelkező munkavállalókat foglalkoztatja. Mindemellett, közel azonos aránnyal szerepelnek a középfokú végzettséggel rendelkező munkavállalók a közfoglalkoztatottak összvolumenében, akik már jóval nagyobb potenciált képez(het)nek a versenyszféra munkaadói számára. Annyi bizonyos, hogy a hátrányos helyzetú munkavállalók elsődleges munkaerőpiaci stabil foglalkoztatásához elengedhetetlen a munkaerőpiaci elvárásokat és a térség gazdasági szerkezetét (preventív munkaerőpiaci felmérések) egyaránt figyelembe vevő minőségi emberierőforrás-fejlesztés.

Összességében megállapítható, hogy a hazánkban több évtizedes múltra visszatekintően magas munkanélküliséggel jellemezhetô térségek hátránykompenzációinak oldása kulcskérdés, elsősorban a gazdaságfejlesztés következtében kialakuló - egyes térségek további fejlődési pályáját jelentôsen meghatározó - munkaerőhiány elkerülésében. A munkanélküliség vizsgált idôszak végi alacsony rátáját jelen elemzés - a területi differenciák feltárásával - jelentősen árnyalja, eltekintve a látens munkanélküliek (ismeretlen) számától. Jelen vizsgálat az erőforrások hatékony elosztásának jövőbeni segítésével hozzájárulhat a területfejlesztési politika beavatkozási célterületeinek meghatározásához. Mindezek aktualitását tovább növeli a koronavírusjárvány okozta gazdasági recesszió, ami a rendelkezésre álló adatok alapján hazánkban is a munkanélküliek számának jelentős növekedését generálta. A tényleges gazdasági következményeket még nem ismerjük, mindenesetre a válságkezelésben, a munkanélküliség dinamikus csökkentésében kiemelten fontos szerep hárulhat a közfoglalkoztatásra.

\section{Köszönetnyilvánítás}

Az Innovációs és Technológiai Minisztérium ÚNKP-19-3-Ikódszámú Új Nemzeti Kiválóság Programjának szakmai támogatásával készült.

Területi Statisztika, 2020, 60(5): 517-547; DOI: 10.15196/TS600501 


\section{IRODALOM}

ALPEK, B. L. (2017): Hátrányos belyz̨etú csoportok munkaeró-piaci terïleti esélyei Magyarországon Doktori értekezés, Pécs.

AlPEK, B. L.-TÉSITS, R. (2014): A munkaerőpiaci szenzitivitás Területi Statisztika 54 (4): 333-359.

ALPEK, B. L.-TÉSITS, R. (2019a): A foglalkoztathatóság mérési lehetőségei és térszerkezete Magyarországon Területi Statisz̨tika 59 (2): 164-187. https://doi.org/10.15196/TS590203

ALPEK, B. L.-TÉSITS, R. (2019b): A foglalkoztathatóság térszerkezeti és települési dimenziói Magyarországon Területi Statisżtika 59 (4): 381-389.

https://doi.org/10.15196/TS590402

Alpek, B. L.-TÉsits, R.-HovÁNYI, G. (2018): Spatial inequalities of disadvantage accumulation and their impact on employability in Hungary Regional Statistics 8 (1): 96-119. https://doi.org/10.15196/RS080104

ArTNER, A. (2018): Aggasztó tendenciák az Európai Unió munkaerőpiacán Statisz̧tikai Szemle 96 (4): 341-374. https://doi.org/10.20311/stat2018.04.hu0341

BALCSÓK, I. (2005): A munkanélküliség területi egyenlötlenségei és legjellemzóbb folyamatainak alakulása az 1992-2002 közötti idöszakban Doktori értekezés, Debrecen.

BARTA, GY.-LŐCSEI, H. (2011): The effect of the recent economic crisis on the spatial structure of Hungarian industry Regional Statistics 1 (1): 99-109.

BÉKESI, L. (2011): A magyar gazdaság helyzete, kilátásai, 2002-2010 Ezredforduló - Stratégiai Tanulmányok a Magyar Tudományos Akadémián, 1., Budapest.

BERDE, É. (2005): A pályakezdő diplomások munkanélkülisége Statisztikai Sz̨emle 83 (12): 1094-1110.

BÓDI, F.-OBÁDOVICS, Cs. (2000): Munkanélküliség a vidéki Magyarországon Területi Statisztika 40 (1): 55-68.

BODOR, N. - PÉNZES, J. (2012): Eger komplex vonzáskörzetének dinamikai vizsgálata Tér és Társadalom 26 (3): 30-47. https://doi.org/10.17649/TET.26.3.1929

Bonoli, G. (2010): The political economy of active labour market policy Politics and Society 38 (4): 435-457. https://doi.org/10.1177/0032329210381235

CARD, D. - KLUVE, J. - WEBER, A. (2010): Active labour market policy evaluations: A metaanalysis The Economic Journal, 120 (548): 452-477. https://doi.org/10.1111/j.1468-0297.2010.02387.x

Cseres-Gergely, Zs.-MolnÁr, Gy. (2014): Közmunka, segélyezés, elsődleges és másodlagos munkaerőpiac. In: TÁRKI: Társadalmi Riport pp. 204-225., Budapest.

CSERES-GERGELY, Zs. - MOLNÁR, GY. (2015): Munkapiaci helyzet a közfoglalkoztatásból való kilépés után. In: Munkaerö-piaci Tükör pp. 143-153., MTA Közgazdaság- és Regionális Tudományi Kutatóközpont Közgazdaság-tudományi Intézet, Budapest.

CsoBA, J. (2010): A közfoglalkoztatás régi/új rendszere. Útközben az „Út a munkához” programban Esély 21 (1): 4-24.

DÖVÉNYI, Z. - KOVÁCS, Z. (1999): A szuburbanizáció térbeni-társadalmi jellemzői Budapest környékén Földrajzi Értesitő 48 (1-2): 33-57.

DusEK, T. (2004): A területi elemæések alapjai Regionális Tudományi Tanulmányok 10. ELTE Regionális Földrajzi Tanszék - MTA-ELTE Regionális Tudományi Kutatócsoport, Budapest.

Területi Statisztika, 2020, 60(5): 517-547; DOI: 10.15196/TS600501 
EGEDy, T. (2012): The effects of global economic crisis in Hungary Hungarian Geographical Bulletin 61 (2): 155-173.

FALUVÉGI, A. (2010): Hogyan érintette a gazdasági válság a leghátrányosabb helyzetű kistérségeket? In: Munkaeró-piaci tükör pp. 142-145., MTA Közgazdaság- és Regionális Tudományi Kutatóközpont Közgazdaság-tudományi Intézet, Budapest.

GERŐ, M. - VígVÁRI, A. (2019): Közfoglalkoztatás, redisztribúció és helyi hatalom Esély $30(2): 3-30$

GYÖRGY, L. - VERESS, J. (2016): 2010 utáni magyar gazdaságpolitikai modell Pénzügyi Sẓmle 61 (3): 367-388.

GYŐRI, R. - MIKLE, GY. (2017): A fejlettség területi különbségeinek változása Magyarországon, 1910-2011 Tér és Társadalom 31 (3): 143-165. https://doi.org/10.17649/TET.31.3.2866

JÓZSA, V. (2017): A nagyvállalati beágyazódás vizsgálata helyi szinten három magyar nagyváros példáján Doktori Értekezés, Győr.

KÁLMÁN, J. (2015): A közfoglalkoztatási programok háttere és nemzetközi tapasztalatai In: Munkaerö-piaci tükör pp. 42-58., MTA Közgazdaság- és Regionális Tudományi Kutatóközpont Közgazdaság-tudományi Intézet, Budapest.

KERTESI, G. (2005): Roma foglalkoztatás az ezredfordulón Szociológiai Szemle 16 (2): 57-87.

KERTESI, G. - KÖLLŐ, J. (2006): Felsőoktatási expanzió, „diplomás munkanélküliség” és a diplomák piaci értéke Közgazdasági Szemle 53 (3): 201-225.

KISS, J. P. - SzALKAI, G. (2018): Az ingázás mobilitási jellemzői a legutóbbi népszámlálások adatai alapján Terïleti Statisztikea 58 (2): 177-199. https://doi.org/10.15196/TS580203

KLUVE, J. (2010): The effectiveness of European active labor market programs Labour Economics 17 (6): 904-918. https://doi.org/10.1016/j.labeco.2010.02.004

KÓTI, T. (2018): Spatial differences regarding the chance to leave supported public employment in Hungary's rural periphery Regional Statistics 8 (2): 109-134. https://doi.org/10.15196/RS080210

KÓTI, T. (2019): Efficiency of active labour market policy in Hungary: detransitive settlement structure of supported public employment Folia Geographica, 61 (2): 45-70.

KOvÁCs, I.-RÁCZNÉ, L. Zs. (2011): A szociális és munkaügyi rendszer feladatai és integrációs lehetôségei a tartós munkanélküliség keęelésében Debreceni Egyetem, Szociológia és Szociálpolitika Tanszék, Debrecen.

KOZMA, G. (2010): Az Európai Unió regionális politikája. In: SÜLI-ZAKAR, I.: Terület- és településfejlesztés alapjai II. pp. 213-237., Dialóg-Campus Kiadó, Budapest-Pécs.

KŐSZEGFALVI, GY. (2009): Infrastruktúra, életkörülmények Területi Statisztika, 49 (1): 47-65.

LAKY, T. (2002): Munkaerôpiac Magyarországon 2001-ben. In: Munkaerópiaci tükör pp. 15-38., MTA Közgazdaságtudományi Intézet, Budapest.

LENGYEL, I. (2006): A regionális versenyképesség értelmezése és piramismodellje Területi Statisztika 46 (2): 131-147.

LŐCSEI, H. (2010): A gazdasági világválság hatása a munkanélküliség területi egyenlőtlenségeire In: Munkaeró-piaci tükör pp. 126-141., MTA Közgazdaságtudományi Intézet, Országos Foglalkoztatási Közalapítvány, Budapest.

Területi Statisztika, 2020, 60(5): 517-547; DOI: 10.15196/TS600501 
MolnÁR, E. - DÉzSI, Gy. - Lengyel, I. M. - KoZMA, G. (2018): Vidéki nagyvárosaink gazdaságának összehasonlító elemzése Területi Statisztika 58 (6): 610-637. https://doi.org/10.15196/TS580604

MorAn, P. A. P. (1948): The interpretation of statistical maps Journal of the Royal Statistical Society Series B (Methodological) 10 (2): 243-251. https://doi.org/10.1111/j.2517-6161.1948.tb00012.x

Nemes NAgy, J. (2005): Fordulatra várva - a regionális egyenlőtlenségek hullámai, In: DÖVÉNYI, Z. - SCHWEIZER, F. (szerk.) A földrajz dimenziói pp. 141-158., MTA FKI, Budapest.

OBÁDOvics, Cs. (2004): A vidéki munkanélküliség térségi eloszlásának elemzése Doktori értekezés, Szent István Egyetem, Gödöllő.

PÁsZTOR, I. Z.-PÉNZES, J. (2012): Foglalkoztatási krízis és jövedelmi periférizálódás Északkelet-Magyarországon a roma népesség arányainak tükrében Terïleti Statisztika 52 (4): 353-371.

PÉNZES, J. (2013): A foglalkoztatottság, az ingázás és a jövedelmi szint összefüggései Északkelet- és Északnyugat-Magyarországon Területi Statisztika 53 (3): 202-224.

PÉNZES, J. (2014): Periférikus térségek lehatárolása - dilemmák és lehetöségek Didakt Kiadó, Debrecen.

PÉnZES, J. - KISS, J. P. - DEÁK, A. - APÁTI, N. (2018): Térségi sokszínűség és stabilitás: az iskolázottság települési szintű egyenlőtlenségeinek változása Magyarországon 1990-2011 között Területi Statisztika 58 (6): 567-594. https://doi.org/10.15196/TS580602

RECHNITZER, J. (2019): Nagyvárosok a magyar területi politikában és területfejlesztésben a rendszerváltozástól napjainkig Tér és Társadalom 33 (1): 1-26. https://doi.org/10.17649/TET.33.1.3069

ROZGONYI-HORVÁTH, Á. (2018): A periférikus területeken élő aktív korúak munkaerőpiaci kapcsolatai - egy belső periférián található zsáktelepülés példáján Területi Statisztika 58 (4): 417-443. https://doi.org/10.15196/TS580405

SzABÓ, A. (2013): A közfoglalkoztatás jelentősége két gazdasági recesszió tükrében Esély 24 (4): 73-86.

TAgAi, G.-Bernard, J.-Šimon, M.-KoÓs, B. (2018): Two faces of peripherality: labour markets, poverty, and population dynamics in Hungary and Czechia Regional Statistics 8 (2): 19-45. https://doi.org/10.15196/RS080204

Teperics, K. - SzILÁGYiné CZIMre, K. - MÁRTON, S. (2016): A tanuló városok és régiók területi megjelenése és társadalmi-gazdasági mutatókkal való kapcsolata Magyarországon Educatio 25 (2): 245-259.

TÉsITS, R.-ALPEK, B. L. (2013): A leghátrányosabb helyzetű álláskeresők mobilitásvizsgálatának új módszerei Humán Innovációs Szemle 4 (1-2): 46-64.

TóTH, G. (2003): Területi autokorrelációs vizsgálat a Local Moran I módszerével Tér és Társadalom 17 (4): 39-49. https://doi.org/10.17649/TET.17.4.914

TÓTH, G. (2018): Az elérhetöség szerepe a térszerkęet társadalomföldrajzi vizsgálatában MTA doktori értekezés, Budapest.

VÁRADI, M. M. (2016): Értékteremtő közfoglalkoztatás periférikus vidéki terekben Esély 27 (1): 30-56.

Területi Statisztika, 2020, 60(5): 517-547; DOI: 10.15196/TS600501 


\section{INTERNETES HIVATKOZÁSOK}

2011. évi CVI. törvény: (VII. 19.) A kö̊foglalkoztatásról és a közfoglalkoztatáshoz kapcsolódó, valamint egyéb törvények módositásáról https:/ / net.jogtar.hu/jogszabaly?docid=a1100106.tv.

Európai Bizottság (2010): Közlemény https://ec.europa.eu/eu2020/pdf/1_HU_ACT_part1_v1.pdf.

Európai Bizottság (2016): Országjelentés https://ec.europa.eu/info/sites/info/files/cr_hungary_2016_en.pdf.

Eurostat (2017): Newsrelease, 2015 GDP per capita in 276 EU regions - Four regions over double the EU average... and still nineteen regions below half of the average 52/2017 - 30 March 2017, Luxembourg.

Hétfa Kutatóintézet (2018): A kö̊foglalkoztatás hatása a helyi gazdaságra, helyi társadalomra https://kozfoglalkoztatas.kormany.hu/download/f/fc/42000/BM_k\%C3\%B6z foglalkozt \%C3\%A1s_Tanulm\%C3\%A1ny_20180928-merged.pdf

KSH (2018): Módszertani dokumentáció https://www.ksh.hu/apps/meta.objektum?p_lang=HU\&p_menu_id=110\&p_ot _id=100\&p_obj_id=ABBA\&p_session_id=

KSH (2019): Munkaeröpiaci folyamatok http://www.ksh.hu/docs/hun/xftp/idoszaki/mpf/mpf1906.pdf 